\title{
Planktonic ciliates below sea ice in Franklin Bay, Canada
}

\author{
TOSHIKAZU SUZUKI ${ }^{1, *} \&$ TAKASHI OTA ${ }^{2}$ \\ ${ }^{1}$ Faculty of Fisheries, Nagasaki University, Nagasaki 852-8521, Japan \\ ${ }^{2}$ Department of Biological Engineering, Ishinomaki Senshu University, Ishinomaki 986-8580, Japan
}

Received 23 October 2010; Accepted 30 March 2011

\begin{abstract}
Planktonic ciliates below sea ice in Franklin Bay, Canada were studied in terms of their taxonomic composition and species descriptions. They occurred at an abundance of 2,400 cells L $\mathrm{s}^{-1}$ and a biovolume of $4.24 \times 10^{6} \mu^{3} \mathrm{~L}^{-1}$. Loricate ciliates (Tintinnida, Spirotrichea) occupied a very small percentage of the total both in terms of abundance $(1.7 \%)$ and biovolume (1.9\%). On the other hand, aloricate ciliates were predominant; in particular Myrionecta rubra (Cyclotrichida, Litostomatea) in terms of abundance (50\%) and Lohmaniella oviformis (Choreotrichida, Spirotrichea) in terms of biomass (19.2\%). Diagnoses and descriptions are given for ten aloricate species; eight of these species (Leegaardiella ovalis, Lohmaniella oviformis, Tontonia gracillima, Strombidium acutum, S. constrictum, $S$. dalum, S. epidemum, Myrionecta rubra) were identifiable in the present material. Compared with previous descriptions, six of these species (not S. constrictum or M. rubra) have more or less distinct characters incompatible with reported intraspecific variations.
\end{abstract}

Key words: Franklin Bay, planktonic ciliates, sea ice, species description

\section{Introduction}

Planktonic ciliates occur universally in the surface ocean and have been recognized as one of the important components in microbial food webs (e.g. Azam et al. 1983). Among the planktonic ciliates, aloricate forms are frequently predominant rather than tintinnid ciliates (e.g. Suzuki \& Taniguchi 1998, Suzuki 1999). The former, however, have not been investigated globally especially from a faunistic viewpoint, because their taxonomic identification and morphological observations are generally laborious and time-consuming (Wilbert 1975, Montagnes \& Lynn 1987). Furthermore, available criteria for their species identification are often insufficient for practical use, especially in small-sized species; descriptive information is limited and hence morphological variation in each species is not fully characterized compared with the situation in tintinnid ciliates. These difficulties prevent the development of further ecological studies on planktonic ciliates, such as population dynamics and studies of species diversity.

Sea ice is observed in higher latitudes, especially in winter, in both hemispheres and covers up to $7 \%$ of the earth's surface (Dieckmann \& Hellmer 2003). It provides favorable habitats for ice algae and various consumers, especially

*Corresponding author: Toshikazu Suzuki; E-mail, tsuzuki@nagasakiu.ac.jp around the boundary between the ice-bottom and the water column (Knox 1994, Schnack-Schiel 2003). Although planktonic ciliates may be an important component of the microbial fauna (Lizotte 2003), ecological information on them is extremely rare because the frigid climate is inhibitory for investigations. Fortunately, through a precious opportunity to collect planktonic ciliate specimens in icecovered Franklin Bay, Canada, it has become possible to offer here some basic information on ciliate ecology below sea ice.

In this study, the taxonomic composition of planktonic ciliates dwelling below sea ice in Franklin Bay was investigated and detailed morphometrics of the dominant aloricate species were described to allow comparisons with previous descriptions. Furthermore, an attempt was made the biogeographic distribution of each aloricate species through referral to reliable articles published in the literature.

\section{Materials and Methods}

Sampling was carried out on 10 May 2004 at an overwintering station of CASES 2004 in Franklin Bay, Canada $\left(70^{\circ} 02^{\prime} \mathrm{N}, 126^{\circ} 18^{\prime} \mathrm{W}\right.$; Fortier and Barber 2008). The water sample was collected with a Niskin-type water sampler at $0.2 \mathrm{~m}$ depth below the sea ice ( $1.8 \mathrm{~m}$ thickness). Water temperature and salinity were simultaneously measured with a CTD (Sea-Bird 9). Chlorophyll a concentration was mea- 


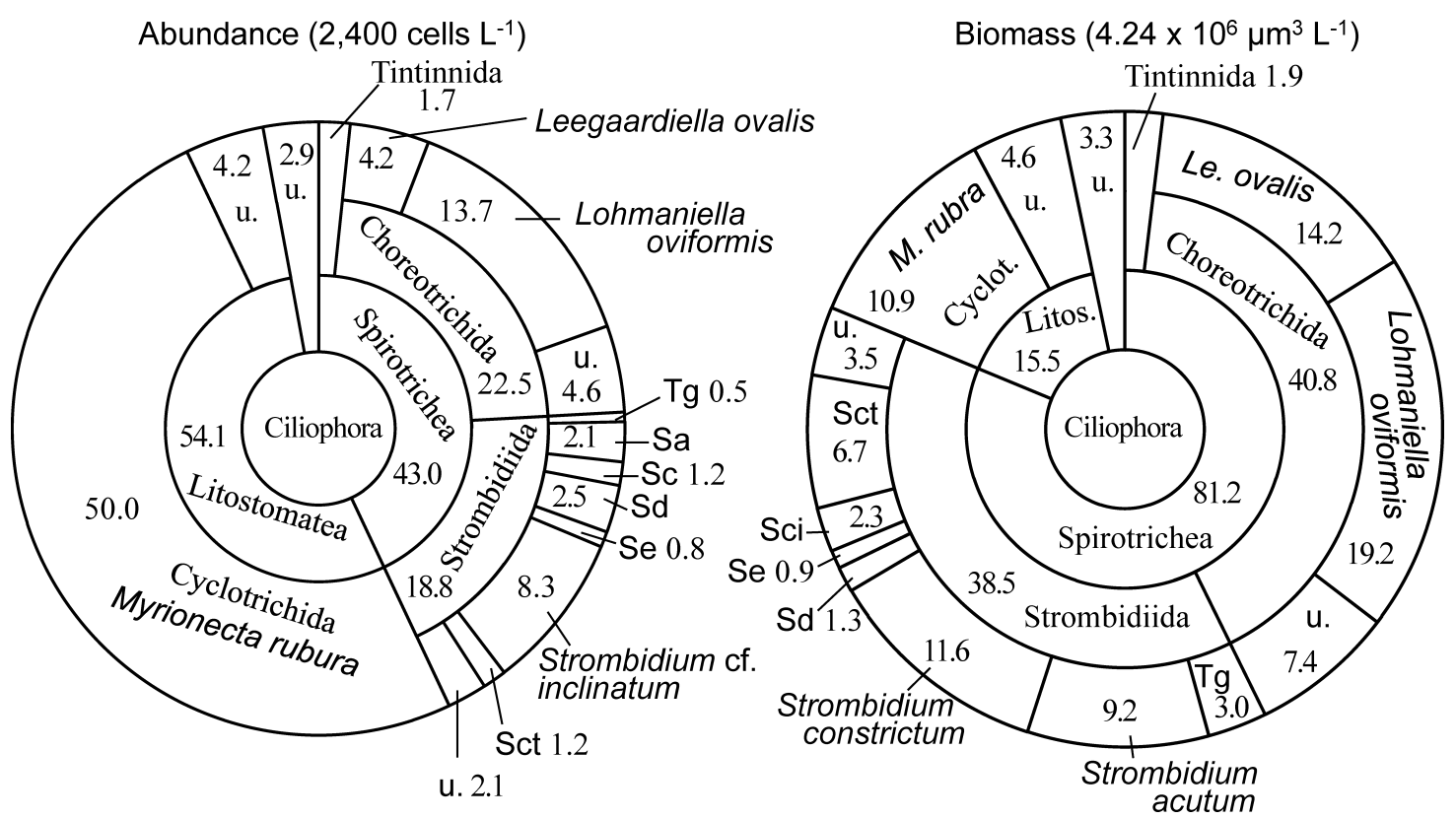

Fig. 1. Taxonomic compositions of planktonic ciliates that occurred below sea ice in Franklin Bay on 10 May 2004. Left circle is in terms of abundance and right one in biovolume. Numerals show percentage of each group. Sa: Strombidium acutum, Sc: Strombidium constrictum, Sd: Strombidium dalum, Se: Strombidium epidemum, Sci: Strombidium cf. inclinatum, Sct: Strombidium cf. taylori, Tg: Tontonia gracillima, u.: unidentified.

sured by fluorometry after filtration of a $100 \mathrm{~mL}$ water subsample onto a GF/F filter (Parsons et al. 1984). Specimens in $650 \mathrm{~mL}$ were fixed with Bouin's solution at a final concentration of $10 \%$. After returning to the laboratory, ciliates were concentrated, impregnated and mounted with the quantitative protargol stain (QPS) method (Montagnes \& Lynn 1987), while the two steps for producing a purple-gray tone, placing in the gold chloride solution and the following oxalic acid solution, were omitted following the general protargol impregnation method (e.g. Wilbert 1975) to observe microstructures more clearly. Enumeration and observation were done under a light microscope with oil immersion lenses of $20 \times, 40 \times$ and $100 \times$. For species descriptions, as many well-conditioned specimens, e.g. cell body not being damaged by fixation and staining of an appropriate tone for detailed observations as possible, were selected. Eight permanent slides, where all plankters that occurred in the 650 $\mathrm{mL}$ sea water sample were stained with silver protein and mounted, without any missing, were deposited in the collection of the Faculty of Fisheries, Nagasaki University. Systematics is mainly according to Lynn \& Small (2000).

\section{Results and Discussion}

Water temperature was $-1.6^{\circ} \mathrm{C}$ and salinity was $30.7 \mathrm{psu}$. Chlorophyll $a$ concentration was $0.53 \mu \mathrm{g} \mathrm{L}^{-1}$. Among the autotrophic microplankton, diatoms were predominant $\left(1.8 \times 10^{4}\right.$ cells $\left.\mathrm{L}^{-1}\right)$, especially pennate types $(78 \%)$.

The standing crop of planktonic ciliates was 2,400 cells $\mathrm{L}^{-1}$ in terms of abundance and $4.24 \times 10^{6} \mu \mathrm{m}^{3} \mathrm{~L}^{-1}$ in bio- volume without correcting for cell shrinkage due to Bouin's fixation (Fig. 1). Ciliate/chlorophyll $a$ ratio was 4,530 cells $\mu \mathrm{g}^{-1}$, which is in the higher half of the general range observed in the open ocean $\left(100-10,000\right.$ cells $\mu \mathrm{g}^{-1}$ : Suzuki \& Taniguchi 1998). Class Spirotrichea was predominant $(81.2 \%)$ in terms of biovolume composition, while it was slightly subdominant $(43.0 \%)$ to the class Litostomatea $(54.1 \%)$ in terms of abundance. Among the spirotrich ciliates loricate forms (order Tintinnida) were a minor component $(1.7 \%$ of abundance and $1.9 \%$ of biovolume); this subordinate tendency is the same as the general trend for the open ocean (Suzuki \& Taniguchi 1998).

Cell size of planktonic ciliates ranged from 7 to $33 \mu \mathrm{m}$ in equivalent spherical diameter (ESD) for Bouin's fixed specimens (Fig. 2): mean ESD was $13 \mu \mathrm{m}$ and median was $10 \mu \mathrm{m}$. Even when the cell diameter is corrected with a QPS shrinkage factor of 0.74 , which is estimated from a factor of $0.4(\sqrt[3]{0.4} \approx 0.74)$ measured in terms of cell volume (Jerome et al. 1993), more than $70 \%$ of individuals belonged to the nanoplankton category $(2-20 \mu \mathrm{m})$.

Ten species were frequently observed and clearly identifiable: nine species belonged to the class Spirotrichea and the other to the class Litostomatea (Fig. 1). Descriptions of their morphology and other remarks, based on observations on their QPS specimens (Montagnes \& Lynn 1987), are as follows.

Class Spirotrichea Bütschli, 1889

Subclass Choreotrichia Small \& Lynn, 1985

Order Choreotrichida Small \& Lynn, 1985 
Suborder Leegaardiellina Laval-Peuto, Grain and Deroux, 1994

Family Leegaardiellidae Lynn \& Montagnes, 1988

Genus Leegaardiella Lynn \& Montagnes, 1988

Leegaardiella ovalis Lynn \& Montagnes, 1988 (Figs 3 \& 4, Table 1)

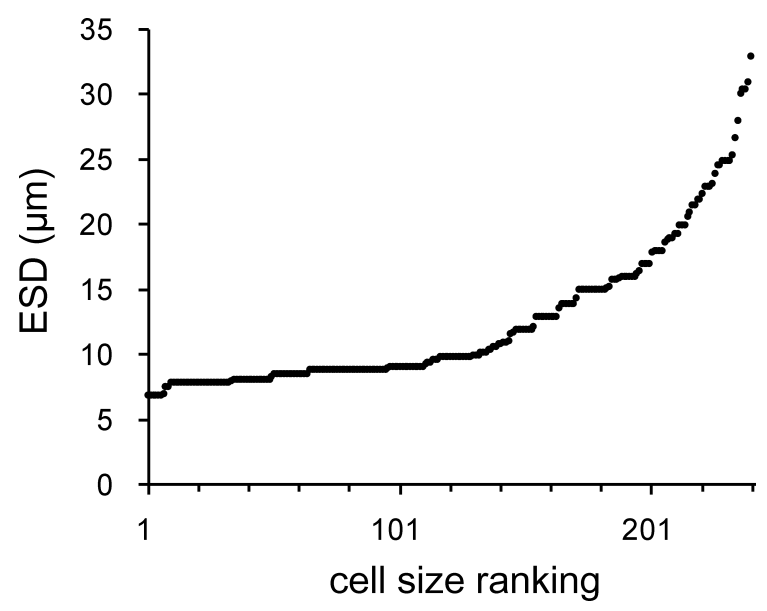

Fig. 2. Relationship between cell size ranking (from small to large) and cell size (equivalent spherical diameter: ESD) of planktonic ciliates under sea ice in Franklin Bay. Two hundred and thirty four individuals were randomly selected and investigated.

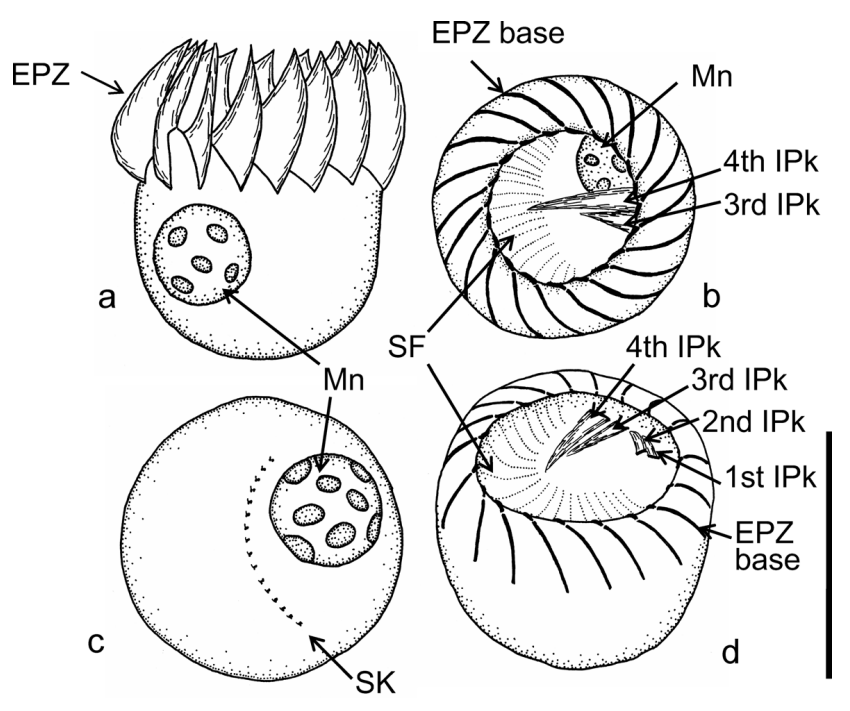

Fig. 3. Schematic figures of protargol-stained Leegaardiella ovalis. a, lateral view showing external polykinetid zone (EPZ) and a macronucleus $(\mathrm{Mn})$; b, anterior view showing EPZ base composed of two segments, two internal polykinetids (IPk) (3rd and 4th in counter clockwise order), supportive fibers (SF) and $\mathrm{Mn}$; c, posterior view showing an arched somatic kinety (SK) and $\mathrm{Mn}$; d, anterior-lateral view showing IPk, SF and EPZ base composed of two segments. Scale bar: $20 \mu \mathrm{m}$.

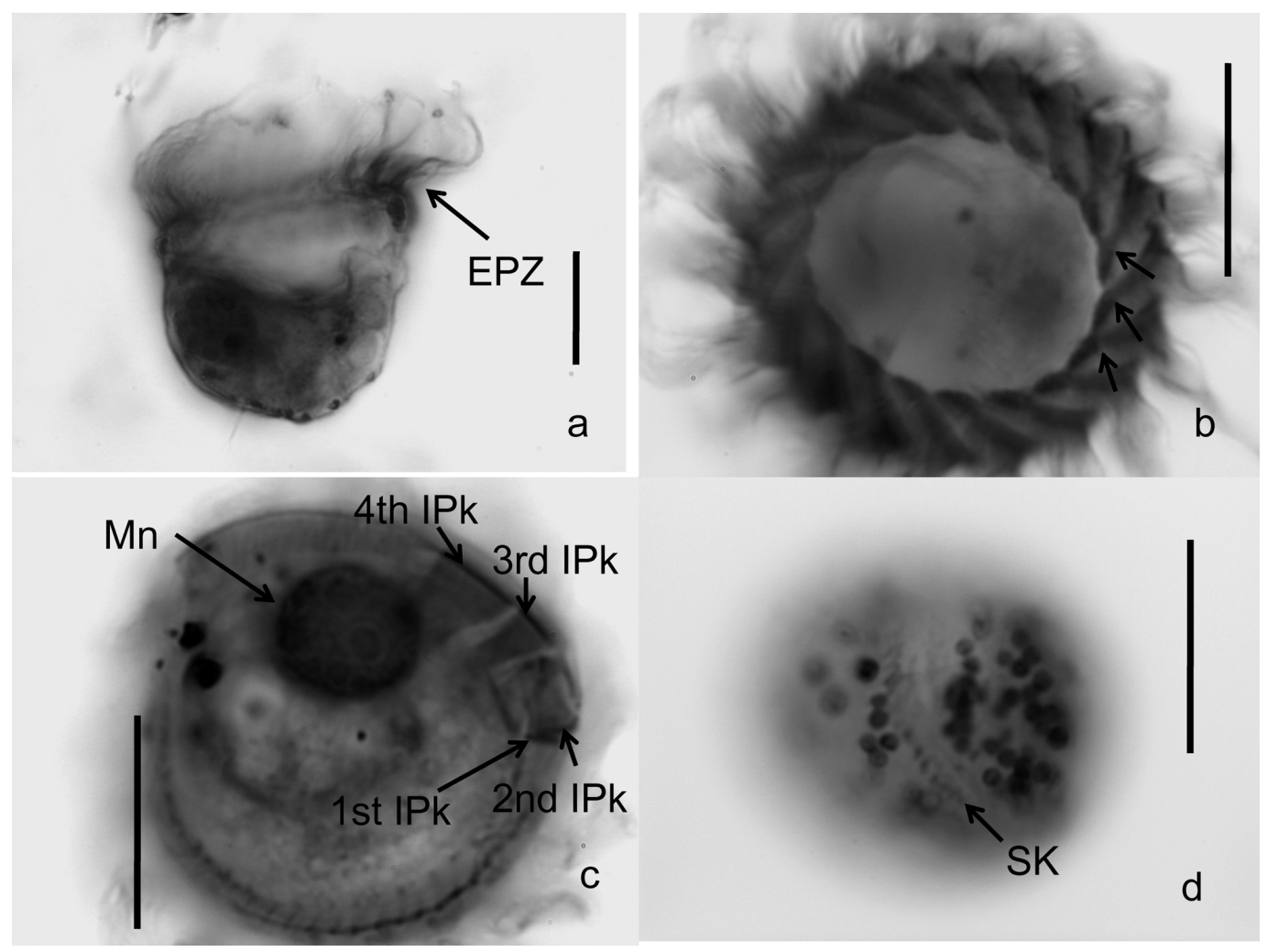

Fig. 4. Microphotographs of protargol-stained Leegaardiella ovalis. a, lateral view showing external polykinetid zone (EPZ); b, anterior view showing gaps between two segments in each external polykinetid (arrowed); c, anterior view showing a macronucleus (Mn) and four internal polykinetids (IPk) (direction of 1st and 2nd IPk is different from the others); d, posterior view showing an arched somatic kinety (SK) and many dark-stained particles. Scale bar: $10 \mu \mathrm{m}$. 
Table 1. Morphological characteristics of two Choreotrichida species below sea ice in Franklin Bay.

\begin{tabular}{|c|c|c|c|c|c|c|c|c|c|}
\hline Species & Cell shape & $\begin{array}{l}\text { Length } \\
(\mu \mathrm{m})\end{array}$ & $\begin{array}{l}\text { Width } \\
(\mu \mathrm{m})\end{array}$ & $\begin{array}{c}\mathrm{EPk}^{\mathrm{a}} \\
\text { number }\end{array}$ & $\begin{array}{c}\mathrm{IPk}^{\mathrm{b}} \\
\text { number }\end{array}$ & $\begin{array}{c}\text { EPZ-IPZ } \\
\text { arrangement }\end{array}$ & $\begin{array}{c}\mathrm{SK}^{\mathrm{d}} \\
\text { number }\end{array}$ & $\begin{array}{c}\mathrm{Mn}^{\mathrm{e}} \\
\text { number }\end{array}$ & Mn shape \\
\hline Leegaardiella ovalis & subspherical & $15-28$ & $22-28$ & 19 & 4 & separated & 1 & 1 & almost spherical \\
\hline Lohmaniella oviformis & oval & $13-22$ & $11-17$ & 19-20 & $5-8$ & partially separated & 5 & 1 & reniform \\
\hline
\end{tabular}

${ }^{a}$ EPK: External polykinetid; ${ }^{b}$ IPK: Internal polykinetid; ${ }^{c}$ EPZ-IPZ; External polykinetid zone-internal polykinetid zone; ${ }^{\mathrm{d}}$ SK: Somatic kinety; ${ }^{\mathrm{M}} \mathrm{Mn}$ : Macronucleus.

Leegaardiella ovalis Lynn \& Montagnes, 1988: 653, figs $8 \mathrm{E}-\mathrm{H}$.

Description. Cell subspherical, $15-28 \mu \mathrm{m}$ (mean $=20.3$ $\mu \mathrm{m}, \mathrm{n}=11)$ in length and $22-28 \mu \mathrm{m}$ (mean $=24.9 \mu \mathrm{m}$, $\mathrm{n}=15$ ) in width. External polykinetid zone (EPZ) distinctly separated from internal polykinetid zone (IPZ). EPZ composed of 19 polykinetids $(n=14)$, two unequal segments slightly separated. Internal polykinetids (IPk) lie above an acentric depression and are comprised of 4 polykinetids $(n=6)$; two small, one middle and one large polykinetid in counterclockwise order in anterior view. Direction of the small polykinetids distinctly different from that of the other polykinetids; two small polykinetids face counterclockwise direction, while the others face towards the center. Supportive fibers (SF) observed in oral cavity. One somatic kinety (SK), composed of about 15 dikinetids with the single kinetosome ciliated, around the posterior pole in an arch-shaped arrangement. One macronucleus (Mn), almost spherical in shape, positioned near the IPZ: $8-12 \mu \mathrm{m}$ (mean $=9.8 \mu \mathrm{m}$, $\mathrm{n}=15)$ in length, $7-10 \mu \mathrm{m}$ (mean $=8.6 \mu \mathrm{m}, \mathrm{n}=14)$ in width. Dark-stained particulate substances, sometimes many, on the posterior surface.

Remarks and comparisons. The Franklin-Bay population is very similar to the Isles-of-Shoals population with respect to various morphometric characters such as length (15-28 $\mu \mathrm{m}$ vs. $18-29 \mu \mathrm{m})$, width $(22-28 \mu \mathrm{m}$ vs. $20-28 \mu \mathrm{m})$, external polykinetid number (19 vs. 18-19) and internal polykinetid number (4 vs. 3-5) (Lynn \& Montagnes 1988). However, contrary to the previous description, it sometimes showed an almost insignificant separation of the EPZ between a small inner segment and a large outer one, while the extent of the separation was variable. Furthermore, the direction of the two small internal polykinetids is remarkable (counterclockwise vs. center).

Distribution. This species also occurs in mid- and high latitudes, e.g. Isles-of-Shoals $\left(42^{\circ} 59^{\prime} \mathrm{N}, 70^{\circ} 37^{\prime} \mathrm{W}\right)$ (Lynn \& Montagnes 1988) and Southern Ocean $\left(71^{\circ} \mathrm{S}, 85^{\circ} \mathrm{W}\right.$ and $67^{\circ} \mathrm{S}, 68^{\circ} \mathrm{W}$ ) (Wickham \& Berninger 2007). It might be distributed mainly in cold waters in both hemispheres.

\section{Suborder Lohmanniellina Laval-Peuto, Grain \& Deroux,} 1994

Family Lohmaniellidae Montagnes \& Lynn, 1991

Genus Lohmaniella Leegaard, 1915

Lohmaniella oviformis Leegaard, 1915 (Figs 5 \& 6, Table 1)
Lohmaniella oviformis Leegaard, 1915: 28-30, figs 19-20; Lynn \& Montagnes, 1988: 649-650, figs 7A-D, 9A-B.

Description. Cell oval, 13-22 $\mu \mathrm{m}$ (mean $=20.1 \mu \mathrm{m}, \mathrm{n}=8)$ in length and $11-17 \mu \mathrm{m}$ (mean $=15.6 \mu \mathrm{m}, \mathrm{n}=11$ ) in width. External polykinetid zone (EPZ) composed of 19-20 polykinetids (mean $=19.5$ polykinetids, $\mathrm{n}=11$ ). Internal polykinetid zone (IPZ) composed of 5-8 polykinetids (mean $=6.0$ polykinetids, $n=7$ ) and lies above acentric depression that leads to cytostome. IPZ partially separated from EPZ: three internal polykinetids (1st to 3rd in counterclockwise order in apical view) apparently separated, with the other internal polykinetids (IPk) continuous. IPk size decreases, especially in length (e.g. from 5 to $2 \mu \mathrm{m}$ ), in counterclockwise order. Five somatic kineties (SK) radiate from the posterior pole; each SK composed of 2-5 kinetids (the number sometimes differing among the five SKs in each individual). The kinetid mostly of the non-ciliated dikinetid type, while the non-ciliated monokinetid type is rarely observed. One reniform-shaped macronucleus, 8$11 \mu \mathrm{m}($ mean $=9.5 \mu \mathrm{m}, \mathrm{n}=4)$ in longer axis by $6-8 \mu \mathrm{m}$ (mean $=6.6 \mu \mathrm{m}, \mathrm{n}=9$ ) in shorter axis, positioned excentrically. Oral primordium observed near macronucleus during cell division.

Remarks and comparisons. The Franklin-Bay population is similar to the Isles-of-Shoals population in terms of length (13-22 $\mu \mathrm{m}$ vs. $11-21 \mu \mathrm{m})$, width (11-17 vs. 11-20), external polykinetid number (19-20 vs. 17-21) and IPk number (5-8 vs. 4-6) (Lynn \& Montagnes 1988). It showed, however, differences in IPk arrangement (three IPk separated and the others continuous vs. all distinctly separated) and in SK kinetid type (mostly dikinetid vs. monokinetid). IPk arrangement and SK kinetid type might be somewhat variable among populations.

Distribution. This species also occurs in mid- and high latitudes, e.g. Isles-of-Shoals $\left(42^{\circ} 59^{\prime} \mathrm{N}, 70^{\circ} 37^{\prime} \mathrm{W}\right)$ (Lynn \& Montagnes 1988); central Barents Sea $\left(72-76^{\circ} \mathrm{N}, 30-35^{\circ} \mathrm{E}\right)$ (Jensen \& Hansen 2000); Limfjord (56 $54^{\prime} \mathrm{N}, 9^{\circ} 09^{\prime} \mathrm{E}$ ) (Andersen \& Sørensen 1986), Ellis Fjold (68 $\left.37^{\prime} \mathrm{S}, 7^{\circ} 00^{\prime} \mathrm{E}\right)$ (Grey et al. 1997), while the latter three occurrences were recognized without protargol impregnation. It seems to be distributed mainly in cold waters in both hemispheres. Biomass of this species was $8.14 \times 10^{5} \mu \mathrm{m}^{3} \mathrm{~L}^{-1}$, being the most dominant among the planktonic ciliates $(19.2 \%)$; hence, this species might play an important ecological role below sea ice in Franklin Bay (Fig. 1). 


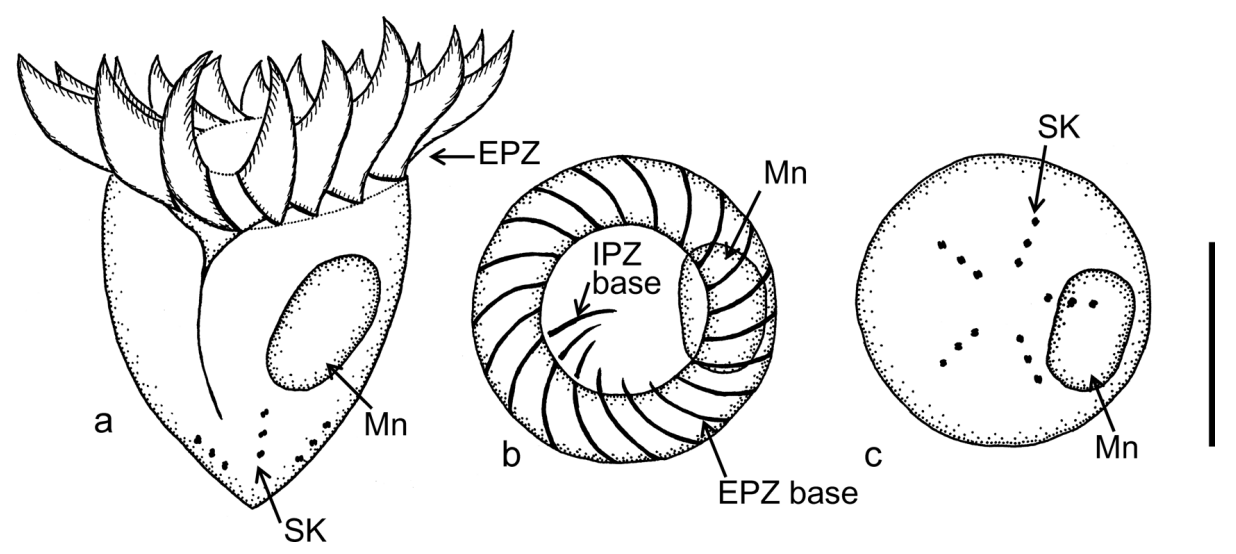

Fig. 5. Schematic figures of protargol-stained Lohmaniella oviformis. a, lateral view showing external polykinetid zone (EPZ), somatic kineties (SK) and a macronucleus (Mn); b, anterior view showing Mn, EPZ base and IPZ base; c, posterior view showing Mn and five SKs. Scale bar: $10 \mu \mathrm{m}$.
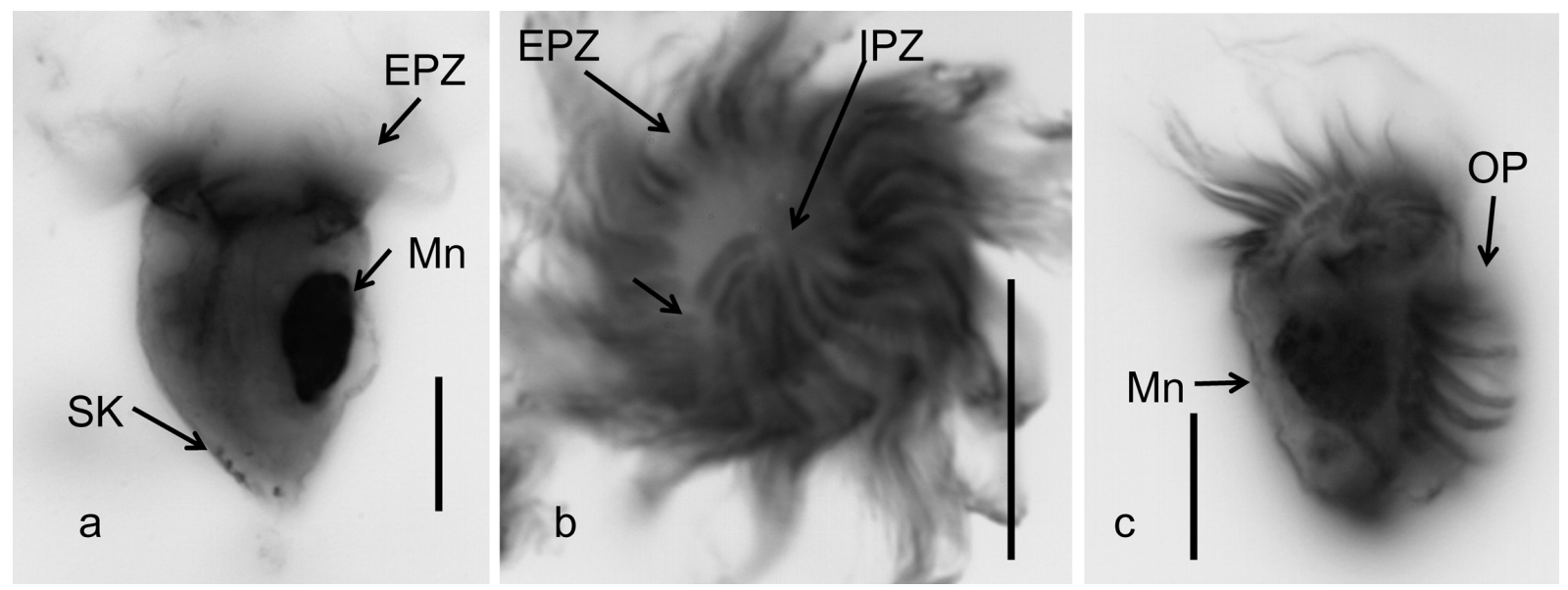

Fig. 6. Microphotographs of protargol-stained Lohmaniella oviformis. a, lateral view showing somatic kineties (SK), external polykinetid zone (EPZ) and a macronucleus (Mn); b, anterior view showing EPZ, internal polykinetid zone (IPZ) and three internal polykinetids (1st to 3rd in counterclockwise order) being separated from EPZ (arrowed); c, lateral view showing oral primordium (OP) near Mn. Scale bar: $10 \mu \mathrm{m}$.

Subclass Oligotrichia Bütschli, 1887

Order Strombidiida Petz \& Foissner, 1992

Family Strombidiidae Fauré-Fremiet, 1970

Genus Tontonia Fauré-Fremiet, 1961

Tontonia gracillima Fauré-Fremiet, 1924 (Figs 7 \& 8, Table 2)

Tonotonia gracillima Fauré-Fremiet, 1924: 72-74, fig. 23; Kahl, 1932: 505-507, fig. 80 (34); Lynn et al., 1988: 261-264, figs 2A-C, 5AB.

Strombidium gracillimum Alekperov \& Mamajeva, 1992: 11-12, fig. 3 (8).

Description. Cell semi-oval with oral groove, 26-35 $\mu \mathrm{m}$ (mean $=30.0 \mu \mathrm{m}, \mathrm{n}=8)$ in length and $21-31 \mu \mathrm{m}$ (mean= $24.8 \mu \mathrm{m}, \mathrm{n}=8)$ in width. Tail (T) contracted, 20-27 $\mu \mathrm{m}$ (mean $=22.1 \mu \mathrm{m}, \mathrm{n}=8)$ in length and $6-8 \mu \mathrm{m}$ (mean $=7.4$ $\mu \mathrm{m}, \mathrm{n}=8$ ) in width; darkly stained fibre lying inside around the base. Anterior polykinetid zone (APZ) comprised of 1315 polykinetids $($ mean $=14.0$ polykinetids, $n=8)$, distinctly separated from ventral polykinetid zone (VPZ). Anterior polykinetids of equal length $(15-20 \mu \mathrm{m})$, surrounding anterior end. VPZ comprised of 13-14 polykinetids (mean= 13.5 polykinetids, $\mathrm{n}=8$ ), lying in a wide ventral groove. Paroral (Po), $11-18 \mu \mathrm{m}$ (mean $=15.5 \mu \mathrm{m}, \mathrm{n}=8)$ in length, composed of ciliated kinetids, lying on the right lip of oral groove. Girdle (G) composed of many kinetids, maybe dikinetids with the one kinetosome ciliated, courses latitudinally at supraequatorial level on dorsal side and longitudinally on both lateral sides. Eight to eleven macronuclei (Mn), almost spherical and 3-6 $\mathrm{mm}$ in diameter. Trichites sometimes observed along the margin of oral groove. Many kinetosomes extending along tail.

Remarks and comparisons. The Franklin-Bay population is similar to the Isles-of-Shoals ciliates (Lynn et al. 1988) with respect to many morphometric characters, while the girdle kinetid type might be different (dikinetids with the one kinetosome ciliated vs. ciliated monokinetids). It is 


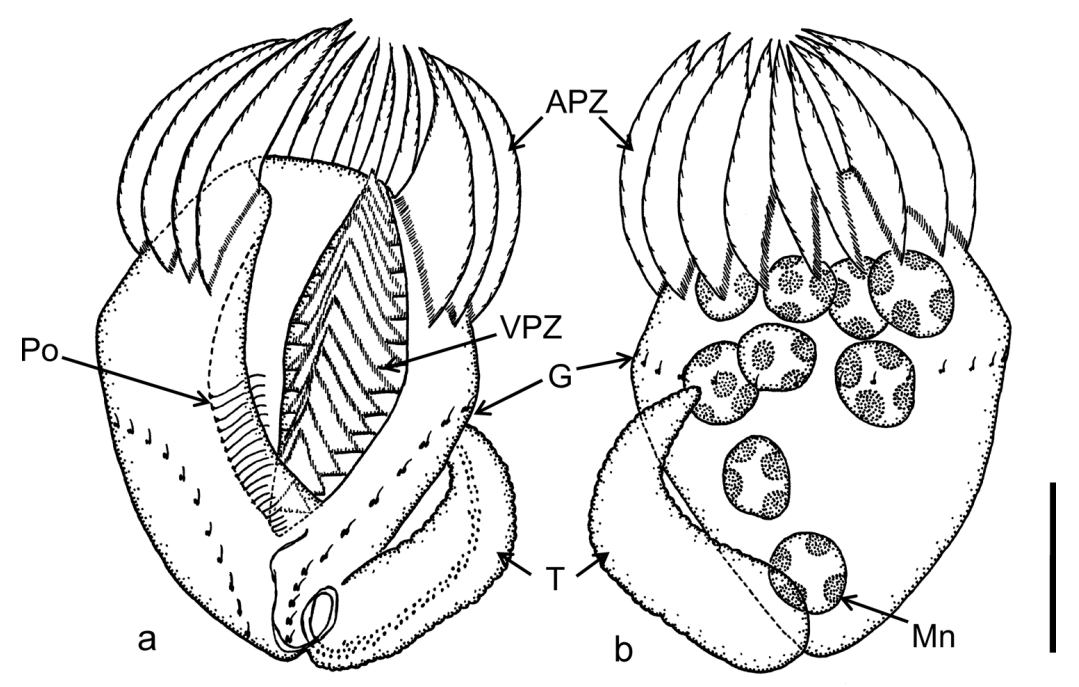

Fig. 7. Schematic figures of protargol-stained Tontonia gracillima. a, ventral view showing anterior polykinetid zone (APZ), ventral polykinetid zone (VPZ), paroral (Po), girdle (G) and tail (T); b, dorsal view showing macronuclei (Mn), APZ, G and T. Scale bar: $10 \mu \mathrm{m}$.
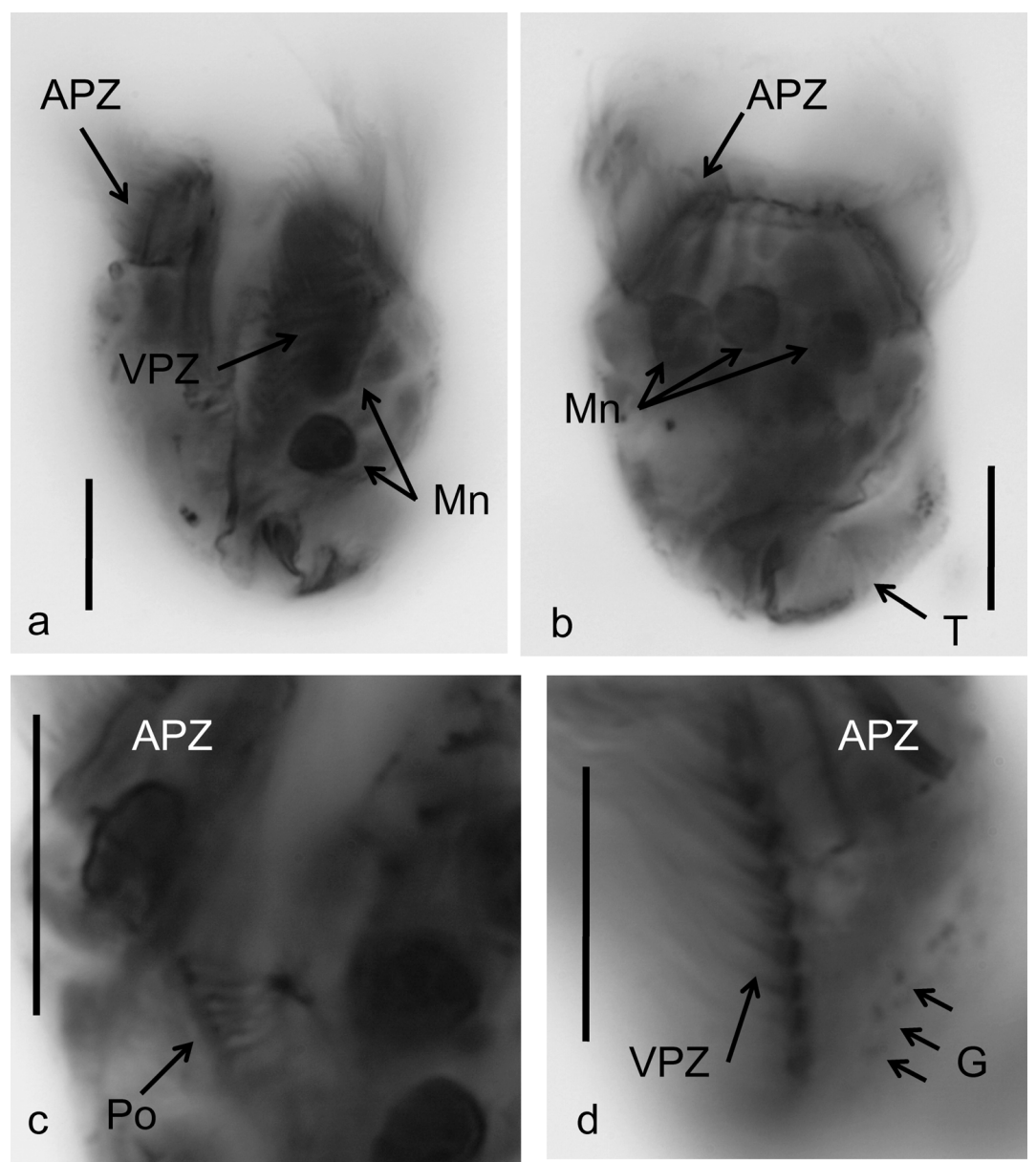

Fig. 8. Microphotographs of protargol-stained Tontonia gracillima. a, ventral view showing anterior polykinetid zone (APZ), ventral polykinetid zone (VPZ) and macronuclei (Mn); b, dorsal view showing APZ, Mn and tail (T); c, oral area showing APZ and paroral (Po) composed of ciliated kinetids; d, right-lateral view showing VPZ, APZ and girdle (G) composed of dikinetids with the single kinetesome ciliated. Scale bar: $10 \mu \mathrm{m}$. 
rather different from the Chukchi-Bering population (Alekperov \& Mamajeva 1992) with respect to body length (26-35 $\mu \mathrm{m}$ vs. 75-90 $\mu \mathrm{m})$, ventral polykinetid number (1314 vs. 10$)$, anterior polykinetid number (13-15 vs. $25-30)$ and macronucleus number (8-10 vs. 35-50). Alekperov \& Mamajeva (1992) suggested T. gracillima should be included in the genus Strombidium. We do not follow this recommendation, however, because the possession of a tail must be a sufficient criterion for generic separation.

Distribution. This species also occurs in mid- and high latitudes, e.g. Croisic Bay $\left(47^{\circ} \mathrm{N}, 2^{\circ} \mathrm{W}\right.$ ) (Fauré-Fremiet 1924), the North Sea $\left(56^{\circ} \mathrm{N}, 6^{\circ} \mathrm{E}\right)$ (Kahal 1932), Isles of Shoals $\left(42^{\circ} 59^{\prime} \mathrm{N}, 70^{\circ} 37^{\prime} \mathrm{E}\right)$ (Lynn et al. 1988) and Chukchi and Bering Seas $\left(63-68^{\circ} \mathrm{N}, 164-180^{\circ} \mathrm{W}\right)$ (Alekperov \& Mamajeva 1992); while the former two occurrences were recognized without protargol impregnation. It might be distributed mainly in cold waters, at least in the northern hemisphere.

Genus Strombidium Claparède \& Lachmann, 1858 Strombidium acutum Leegaard, 1915 (Figs 9 \& 10, Table 2) Strombidium acutum Leegaard, 1915: 31, fig. 21; Lynn et al., 1988: 265, figs 2E, 5E-D; Montagnes et al., 1988: 195 , figs $6 a-b, 14-15$.

Description. Cell wide conical posterior end and round conical anterior end, $23-38 \mu \mathrm{m}($ mean $=29.5 \mu \mathrm{m}, \mathrm{n}=10)$ in

Table 2. Morphological characteristics of seven Strombidiida species below sea ice in Franklin Bay.

\begin{tabular}{|c|c|c|c|c|c|c|c|c|c|}
\hline Species & Cell shape & $\begin{array}{c}\text { Length } \\
(\mu \mathrm{m})\end{array}$ & $\begin{array}{l}\text { Width } \\
(\mu \mathrm{m})\end{array}$ & $\begin{array}{c}\mathrm{APk}^{\mathrm{a}} \\
\text { number }\end{array}$ & $\begin{array}{c}\mathrm{VPk}^{\mathrm{b}} \\
\text { number }\end{array}$ & $\begin{array}{c}\text { APZ-VPZ } \\
\text { arrange- } \\
\text { ment }\end{array}$ & $\begin{array}{c}\mathrm{VK}^{\mathrm{d}} \\
\text { kinetid } \\
\text { number }\end{array}$ & $\begin{array}{c}\mathrm{Mn}^{\mathrm{e}} \\
\text { number }\end{array}$ & Mn shape \\
\hline Tontonia gracillima & semi-oval & $26-35$ & $21-31$ & $13-15$ & $13-14$ & separated & $\begin{array}{l}\text { not } \\
\text { observed }\end{array}$ & $8-11$ & $\begin{array}{l}\text { almost } \\
\text { spherical }\end{array}$ \\
\hline Strombidium acutum & $\begin{array}{l}\text { wide conical posteriorly \& } \\
\text { round conical anteriorly }\end{array}$ & $23-38$ & $21-30$ & 15 & $10-12$ & separated & $7-12$ & 1 & $\begin{array}{l}\text { almost } \\
\text { spherical }\end{array}$ \\
\hline Strombidium constrictum & $\begin{array}{l}\text { conical with 'cap-like' } \\
\text { posterior }\end{array}$ & $39-45$ & $28-33$ & $15-16$ & $11-13$ & separated & 4 & 1 & V-shaped \\
\hline Strombidium dalum & conical & $19-23$ & $8-11$ & $14-15$ & $7-8$ & separated & $4-6$ & 1 & \multirow{4}{*}{$\begin{array}{l}\text { conical } \\
\text { almost } \\
\text { spherical } \\
\text { almost } \\
\text { spherical } \\
\text { U-shaped }\end{array}$} \\
\hline Strombidium epidemum & short conical & $15-21$ & $12-18$ & $14-15$ & $6-7$ & separated & $3-4$ & 1 & \\
\hline $\begin{array}{l}\text { Strombidium } \mathrm{cf} . \\
\text { inclinatum }\end{array}$ & $\begin{array}{l}\text { conical posteriorly \& } \\
\text { cylindrical anteriorly }\end{array}$ & $12-15$ & 9-11 & $\begin{array}{c}19-21 \\
\mathrm{APk}+\mathrm{VPk})\end{array}$ & - & continued & 0 or 2 & 1 & \\
\hline Strombidium cf. taylori & $\begin{array}{l}\text { conical posteriorly \& } \\
\text { cylindrical anteriorly }\end{array}$ & $26-42$ & $20-31$ & $15-16$ & $10-14$ & separated & $4-6$ & 1 & \\
\hline
\end{tabular}

${ }^{\mathrm{a}} \mathrm{APk}$ : Anterior polykinetid; ${ }^{\mathrm{b}} \mathrm{VPk}$ : Ventral polykinetid; ${ }^{\mathrm{c}} \mathrm{APZ}-\mathrm{VPZ}$ : Anterior polykinetid zone-ventral polykinetid zone; ${ }^{\mathrm{d}} \mathrm{VK}$ : Ventral kinety; ${ }^{\mathrm{M}} \mathrm{Mn}$ : Macronucleus.

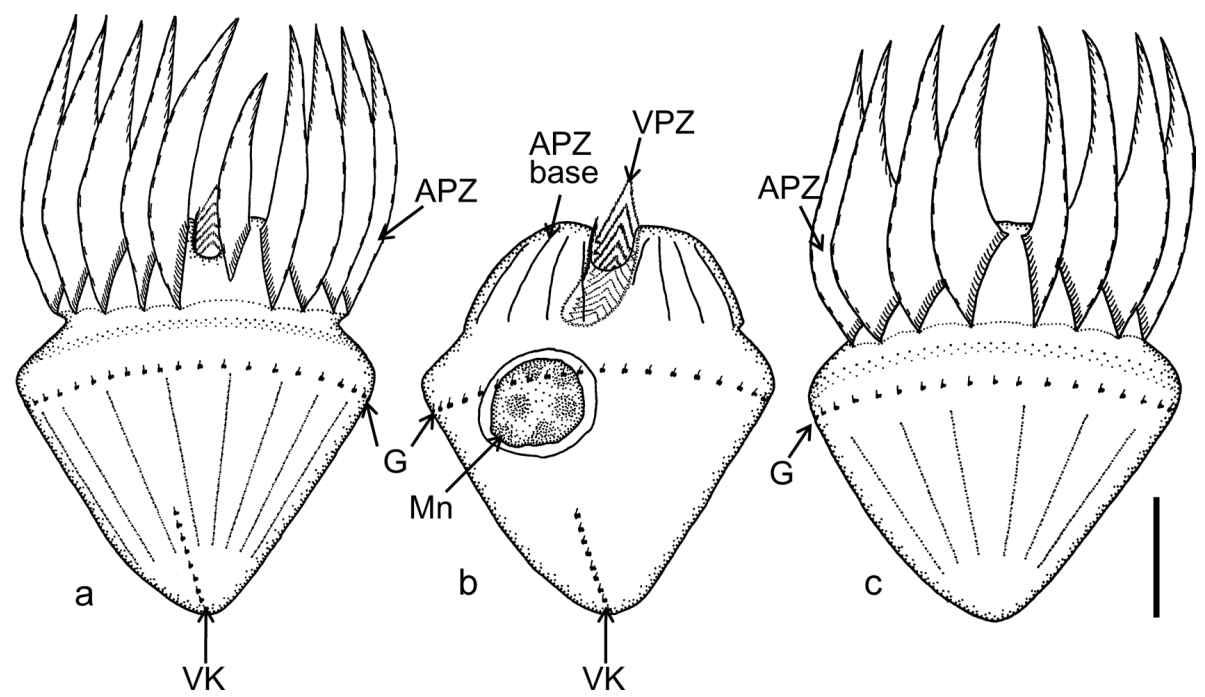

Fig. 9. Schematic figures of protargol-stained Strombidium acutum. a, ventral surface view showing anterior polykinetid zone (APZ), girdle $(\mathrm{G})$ and ventral kinety (VK); b, ventral view showing APZ base, ventral polykinetid zone (VPZ), a macronucleus (Mn), G and VK; c, dorsal surface view showing APZ and G. Scale bar: $10 \mu \mathrm{m}$. 
length and $21-30 \mu \mathrm{m}$ (mean $=25.7 \mu \mathrm{m}, \mathrm{n}=11$ ) in width. An oral cavity enclosed by the ring of anterior polykinetid zone (APZ). APZ composed of 15 polykinetids (mean=15.0 polykinetids, $\mathrm{n}=11$ ) surrounding anterior end, distinctly separated from ventral polykinetid zone (VPZ). Anterior polykinetids (APk) almost of equal length, while one APk, located beside the left margin of the oral groove, has a narrower base and is shifted anteriorly from the ring of APZ. VPZ comprised of $10-12$ polykinetids (mean $=10.5$ polykinetids, $n=11$ ), lying in an oral groove entering posteriorly. Paroral lying on the upper right of the oral groove. Girdle $(G)$ completely surrounding the cell equatorially, composed of dikinetids with the single kinetosome ciliated. Ventral kinety (VK) composed of 7-12 dikinetids with the single kinetosome ciliated. One macronucleus (Mn) almost spherical and covered with thin membrane, $8-13 \mu \mathrm{m}$ (mean $=10.1 \mu \mathrm{m}, \mathrm{n}=11$ ) along longer axis by $8-11 \mu \mathrm{m}$

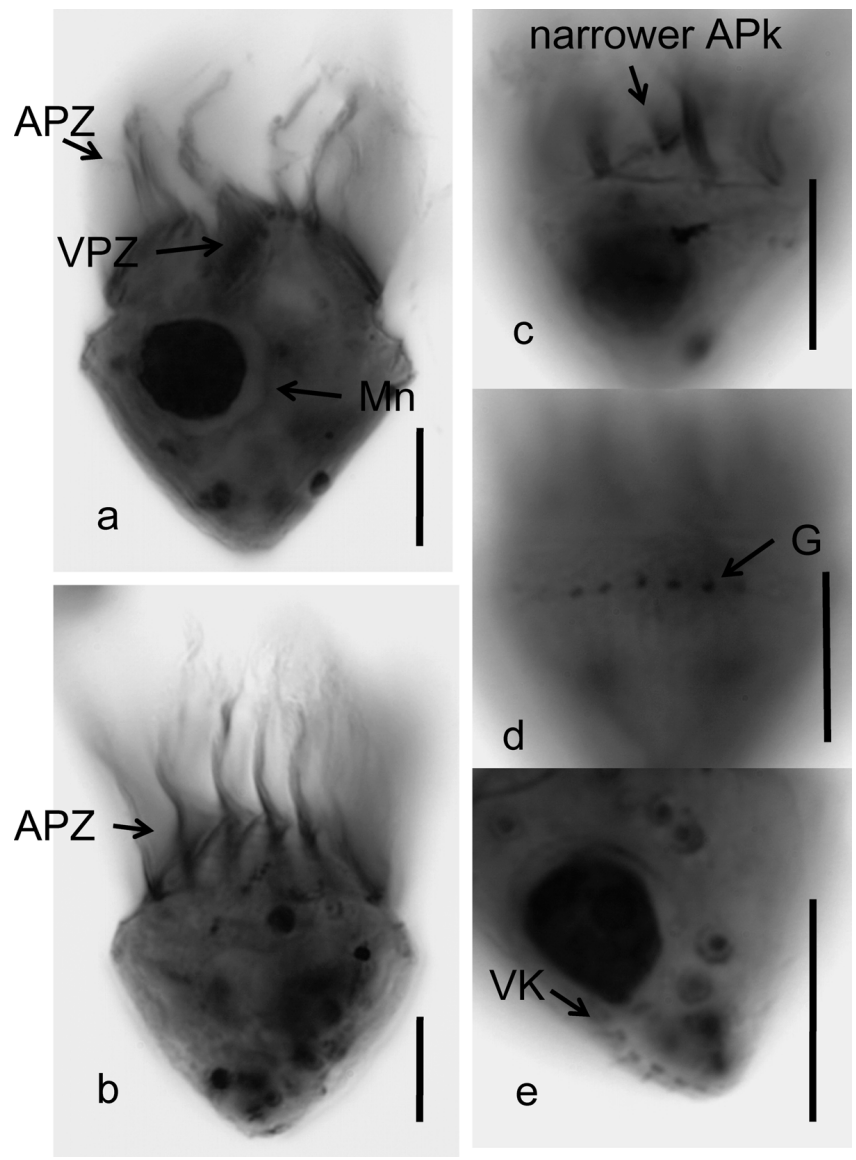

Fig. 10. Microphotographs of protargol-stained Strombidium acutum. a, ventral view showing anterior polykinetid zone (APZ), ventral polykinetid zone (VPZ) and a macronucleus (Mn); b, dorsal view showing APZ; c, right-lateral APZ area showing a narrower anterior polykintetid (APk) located beside the left margin of the oral groove; d, dorsal equatorial area showing girdle $(\mathrm{G})$ composed of dikintids with the single kinetosome ciliated; e, posterior part showing ventral kinety (VK) composed of dikinetids with the single kinetosome ciliated. Scale bar: $10 \mu \mathrm{m}$. (mean $=9.4 \mu \mathrm{m}, \mathrm{n}=11)$ along shorter axis. Trichites numerous and variable in thickness $(0.2-0.5 \mu \mathrm{m})$, inserting from the anterior area of $\mathrm{G}$ and extending internally towards posterior. Beaded strands sometimes recognizable around the APk.

Remarks and comparisons. The Franklin-Bay population is very similar to the Isles-of-Shoals population (Lynn et al. 1988) or the Perch-Pond population (Montagnes et al. $1988)$ in terms of the anterior polykinetid number (15 vs. $12-15$ or $13-18)$ and ventral polykinetid number (10-12 vs. $10-22$ or $9-15)$. However, they are slightly smaller (23-38 $\mu \mathrm{m}$ vs. $28-52$ or $28-53 \mu \mathrm{m}$ in length, $21-30 \mu \mathrm{m}$ vs. $30-48$ or $27-44 \mu \mathrm{m}$ in width) and substantially differ with regards to the type of $\mathrm{G}$ kinetid (dikinetids vs. monokinetids), in VK number (7-12 dikinetids vs. not observed) and in APZ arrangement (one narrower APk shifted anteriorly vs. regularly arranged). A paroal kinety, which was observed in this population as well as in the Isles-of-Shoals population, was not recognized in the Perch-Pond population. These morphological characters may be more or less variable among populations.

Distribution. This species also occurs in mid- and high latitudes, e.g. the Isles of Shoals $\left(42^{\circ} 59^{\prime} \mathrm{N}, 70^{\circ} 37^{\prime} \mathrm{E}\right)$ (Lynn et al. 1988), Perch Pond $\left(41^{\circ} 34^{\prime} \mathrm{N}, 70^{\circ} 35^{\prime} \mathrm{W}\right.$ ) (Montagnes et al. 1988) and Ellis Fjold $\left(68^{\circ} 37^{\prime} \mathrm{S}, 78^{\circ} 00^{\prime} \mathrm{E}\right)$ (Grey et al. 1997), with the lattermost recognized without protargol impregnation. It might be distributed mainly in cold waters in both hemispheres.

Strombidium constrictum (Meunier, 1910) Wulff, 1919 (Figs $11 \&$ 12, Table 2)

Conocylis constricta Meunier, 1910: 147-148, pl. 10, figs 36-37.

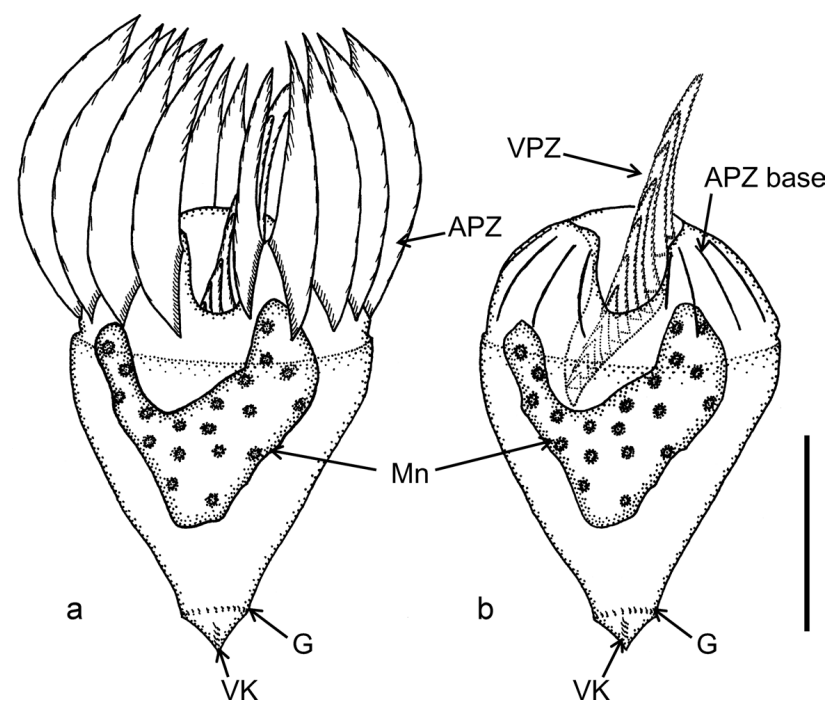

Fig. 11. Schematic figures of protargol-stained Strombidium constrictum. a, ventral view showing anterior polykinetid zone (APZ), a macronucleus (Mn), girdle (G) and ventral kinety (VK); $\mathrm{b}$, ventral view showing APZ base, ventral polykinetid zone (VPZ), Mn, G and VK. Scale bar: $20 \mu \mathrm{m}$. 

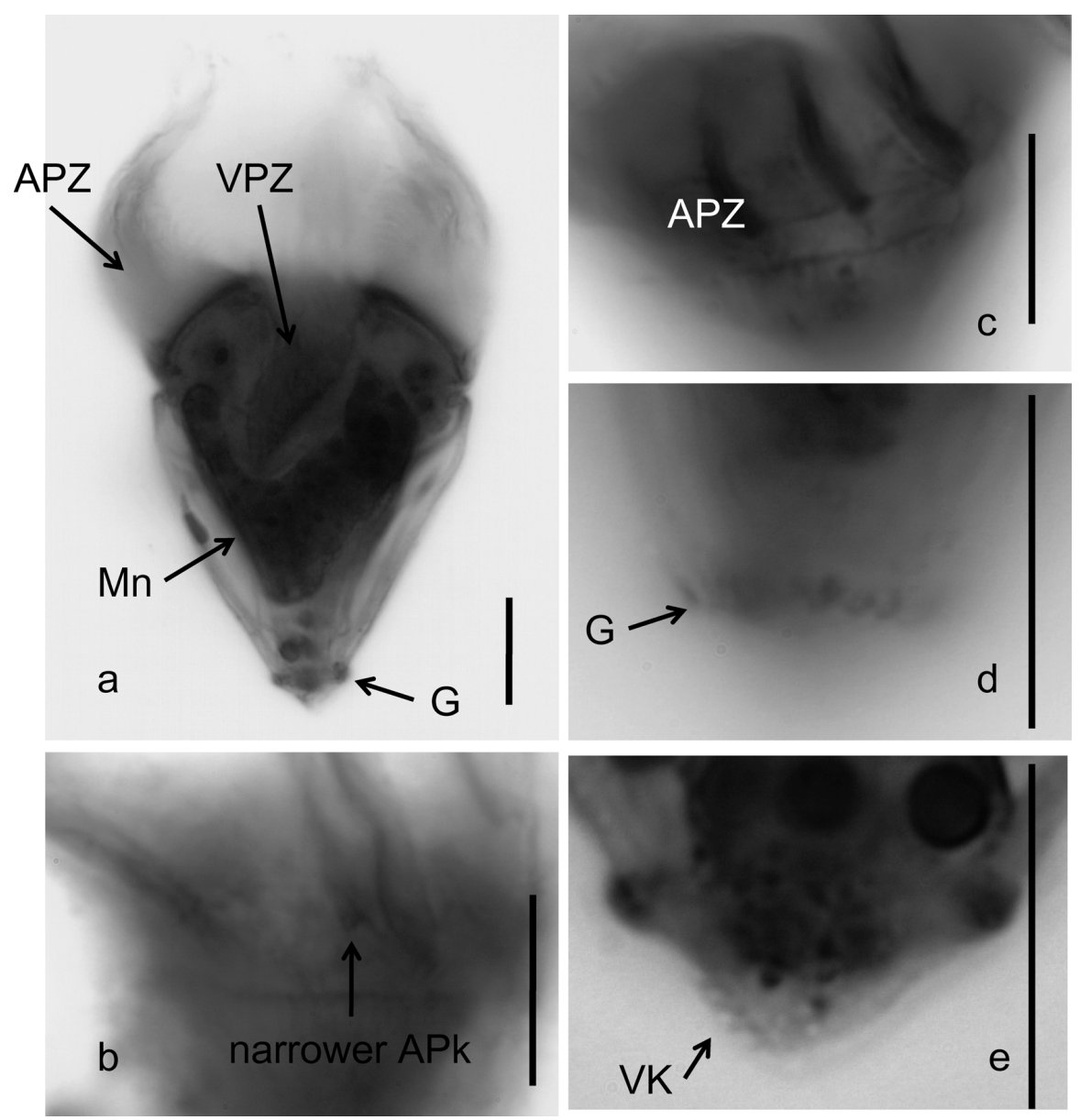

Fig. 12. Microphotographs of protargol-stained Strombidium constrictum. a, ventral view showing anterior polykinetid zone (APZ), ventral polykinetid zone (VPZ), a macronucleus (Mn) and girdle (G); b, APZ area showing a narrower anterior polykinetid (APk) located beside the left margin of the oral groove; c, dorsal view showing APZ; d, posterior part showing girdle (G) composed of dikintids with the single kinetosome ciliated; e, posterior part showing ventral kinety (VK) composed of dikinetids with the single kinetosome ciliated. Scale bar: $10 \mu \mathrm{m}$.

Strombidium constrictum Wulff, 1919: 115, fig. 24; Lynn et al., 1988: 269, figs 3C-E, 6C-D; Lynn \& Gilron, 1993: 63-64.

Description. Cell conical with 'cap-like' posterior end, $39-45 \mu \mathrm{m}$ (mean $=41.8 \mu \mathrm{m}, \mathrm{n}=5)$ in length and $28-33 \mu \mathrm{m}$ (mean $=30.0 \mu \mathrm{m}, \mathrm{n}=5$ ) in width. A deep buccal cavity almost enclosed by the ring of the anterior polykinetid zone (APZ). APZ composed of 15-16 polykinetids (mean=15.4 polykinetids, $n=5$ ) distinctly separated from ventral polykinetid zone (VPZ). Anterior polykinetids (APk) almost of equal length surrounding anterior end, while one APk located beside the right margin of the oral groove has a narrower base and is shifted anteriorly from the ring of APZ. VPZ composed of 11-13 polykinetids (mean $=12.0$ polykinetids, $n=2$ ) lying in the deep buccal cavity. Paroral not observed. Girdle $(\mathrm{G})$ composed of 23-30 dikinetids (mean $=25.4$ dikinetids, $\mathrm{n}=5$ ) with the single kinetosome ciliated, profoundly subequatorial, completely surrounding the cell. Ventral kinety (VK) composed of 4 dikinetids with the single kinetosome ciliated. One "V"-shaped macronu- cleus (Mn) positioned around buccal cavity. Trichites inserting from the posterior area of the APZ and extending internally towards $\mathrm{G}$.

Remarks and comparisons. The Franklin-Bay population is very similar to the Kingston-Harbour population (Lynn \& Gilron 1993) and the Isles-of-Shoals population (Lynn et al. 1988) in cell size $(39-45 \mu \mathrm{m}$ vs. $22-34 \mu \mathrm{m}$ or $39-51 \mu \mathrm{m}$ in length, $22-33 \mu \mathrm{m}$ vs. $17-20 \mu \mathrm{m}$ or $28-39 \mu \mathrm{m}$ in width), anterior polykinetid number (15-16 vs. 14 or 14), ventral polykinetd number (11-13 vs. 9-11 or 8-14). Although there have been only three descriptions based on protargol-impregnated specimens, morphometric variation might be small among the populations.

Distribution. This species occurs in various areas, e.g. Kingston Harbour $\left(17^{\circ} 58^{\prime} \mathrm{N}, 76^{\circ} 48^{\prime} \mathrm{W}\right.$ ) (Lynn \& Gilron 1993), Isles-of-Shoals $\left(42^{\circ} 59^{\prime} \mathrm{N}, 70^{\circ} 37^{\prime} \mathrm{W}\right)$ (Lynn et al. 1988 ) and Grand-Entrée Lagoon $\left(47^{\circ} \mathrm{N}, 61^{\circ} \mathrm{W}\right.$ ) (Trottet et al. 2007), with the lattermost recognized without protargol impregnation. It might be a eurythermal species that is widely distributed, at least in the northern hemisphere. 
Strombidium dalum Lynn, Montagnes \& Small, 1988 (Figs $13 \&$ 14, Table 2)

Strombidium dalum Lynn, Montagnes \& Small, 1988: 265267, fig. 3A, 5F; Lynn \& Gilron, 1993: 62, figs 2C, 7C; Pettigrosso, 2003: 124, fig. 11.

Description. Cell conical, 19-23 $\mu \mathrm{m}$ (mean $=22.1 \mu \mathrm{m}$, $\mathrm{n}=7)$ in length and $8-11 \mu \mathrm{m}($ mean $=9.6 \mu \mathrm{m}, \mathrm{n}=7)$ in width. Oral groove almost enclosed by the ring of the anterior polykinetid zone (APZ). APZ distinctly separated from ventral polykinetid zone (VPZ) and composed of 14-15 polykinetids (mean=14.6, $n=7$ ) of equal length surrounding anterior part. VPZ composed of 7-8 polykinetids (mean $=7.4$ polykinetids, $n=5$ ) and lying in a narrow ventral groove. Paroral not observed. Girdle (G) completely surrounding the cell equatorially, composed of 15-21 dikinetids (mean $=17.0$ dikinetids, $n=7$ ) with the single kinetosome ciliated. Ventral kinety (VK) composed of 4-6 dikinetids (mean $=5.1, \mathrm{n}=7)$ with the anterior kinetosome ciliated. One conical macronucleus $(\mathrm{Mn}), 6-10 \mu \mathrm{m}$ (mean $=$ $7.6 \mu \mathrm{m}, \mathrm{n}=7)$ in length and 4-7 $\mu \mathrm{m}(\operatorname{mean}=5.6 \mu \mathrm{m}, \mathrm{n}=7)$ in maximum width. Trichites not clearly observed. A weakly-stained tail like structure (TLS), about $5 \mu \mathrm{m}$ in length and $2 \mu \mathrm{m}$ in width, sometimes observed at posterior end.

Remarks and comparisons. The Franklin-Bay population is very similar to the Isles-of-Shoals population (Lynn et al. 1988), the Kingston-Harbour population (Lynn \& Gilron 1993), and the Puerto-Cuateros population (Pettigrosso 2003). It has, however, some different morphologi- cal characters such as body length (19-23 $\mu \mathrm{m}$ vs. 13$18 \mu \mathrm{m}$ in Isles-of-Shoals population), girdle kinetid type (dikinetids vs. monokinetids in Isles-of-Shoals population), kinetid number of ventral kinety (4-6 vs. 0 in Isles-of-

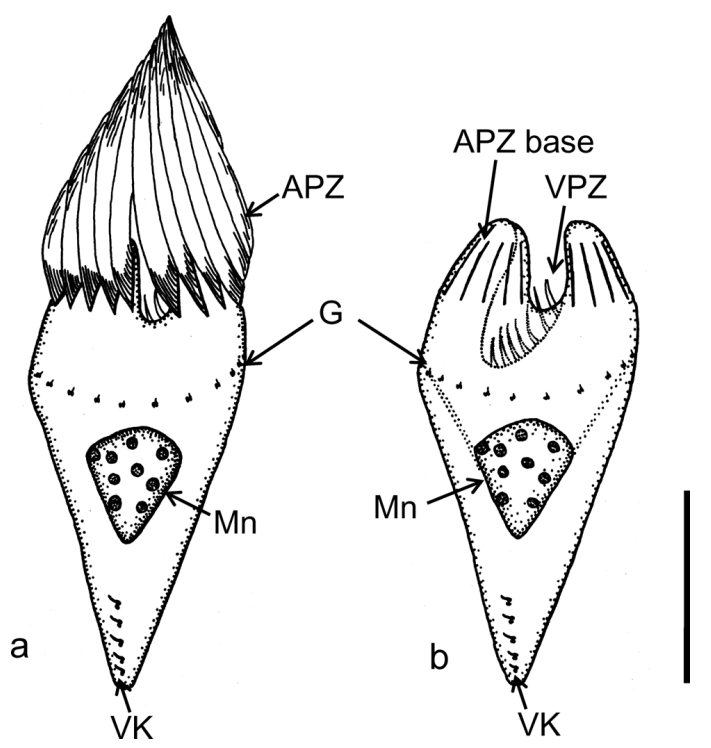

Fig. 13. Schematic figures of protargol-stained Strombidium dalum. a, ventral view showing anterior polykinetid zone (APZ), girdle (G), a macronucleus (Mn) and ventral kinety (VK); b, ventral view showing APZ base, ventral polykinetid zone (VPZ), G, $\mathrm{Mn}$ and VK. Scale bar: $10 \mu \mathrm{m}$.
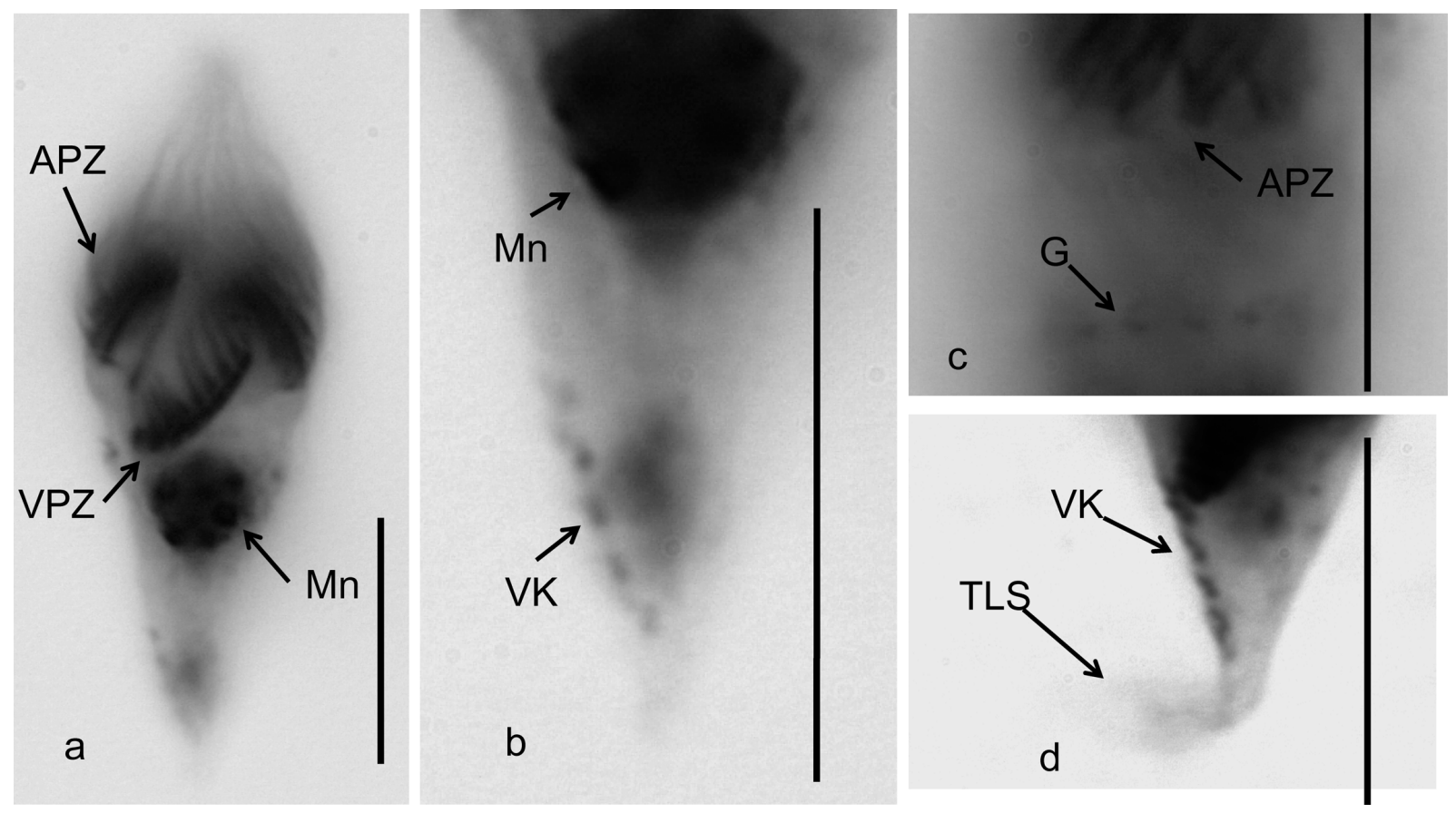

Fig. 14. Microphotographs of protargol-stained Strombidium dalum. a, ventral view showing anterior polykinetid zone (APZ), ventral polykinetid zone (VPZ) and a macronucleus (Mn); b, posterior part showing Mn and ventral kinety (VK) composed of dikinetids with the anterior kinetosome ciliated; c, dorsal part showing APZ and girdle (G) composed of dikinetids with the single kinetosome ciliated; d, posterior view showing VK and tail-like structure (TLS). Scale bar: $10 \mu \mathrm{m}$. 
Shoals and Puerto-Cuatreos populations, or 3 in Jamaica population) and anterior polykinetid style (spiraled torchlike vs. straight in Kingston-Harbour and Puerto-Cuatreros populations). These morphological characters might be more or less variable among populations.

Distribution. This species also occurs in various areas, e.g. Isle of Shoals $\left(42^{\circ} 59^{\prime} \mathrm{N}, 70^{\circ} 37^{\prime} \mathrm{W}\right)$ (Lynn et al. 1988), Puerto Cuatreros $\left(39^{\circ} \mathrm{S}, 62^{\circ} \mathrm{W}\right)$ (Pettigrosso 2003), San Marcos Beach $\left(43^{\circ} 26^{\prime} \mathrm{N}, 00^{\circ} 14^{\prime} \mathrm{W}\right)$ (Fernandez-Leborans \& Fernandez-Fernandez 1999) and Kingston Harbour $\left(17^{\circ} 58^{\prime} \mathrm{N}, 76^{\circ} 48^{\prime} \mathrm{W}\right)$ (Lynn \& Gilron 1993). It might be a eurythermal species and be widely distributed in both hemispheres.

\section{Strombidium epidemum Lynn, Montagnes \& Small, 1988} (Figs 15 \& 16, Table 2)

Strombidium epidemum Lynn, Montagnes \& Small, 1988: 267-269, figs 3B, 6A-B; Lynn \& Gilron, 1993: 62, figs $5 \mathrm{~A}, 7 \mathrm{~A}-\mathrm{B}$.

Description. Cell short conical, $15-21 \mu \mathrm{m}$ (mean $=17.2$ $\mu \mathrm{m}, \mathrm{n}=10$ ) in length and $12-18 \mu \mathrm{m}$ (mean $=14.5 \mu \mathrm{m}$, $\mathrm{n}=11$ ) in width. An oral cavity fairly exposed on the ventral surface. Anterior polykinetid zone (APZ) composed of 14-15 polykinetids (mean $=14.2$ polykinetids, $\mathrm{n}=11$ ),

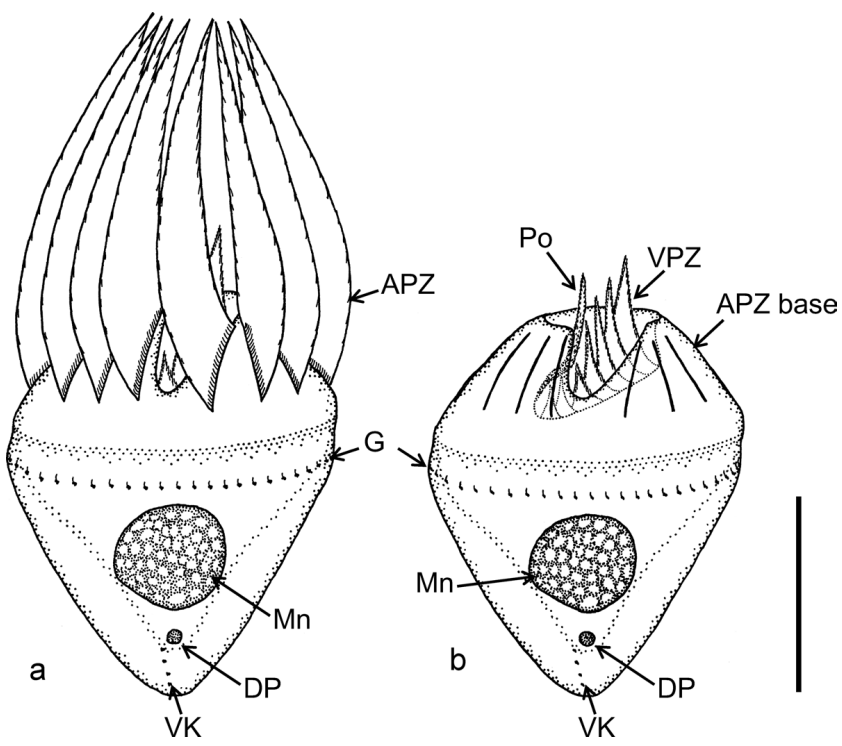

Fig. 15. Schematic figures of protargol-stained Strombidium epidemum. a, ventral view showing anterior polykinetid zone (APZ), girdle (G), a macronucleus $(\mathrm{Mn})$, a dark-stained particle (DP) and ventral kinety (VK); b, ventral view showing paroral (Po), ventral polykinetid zone (VPZ), APZ base, G, Mn, DP and VK. Scale bar: $10 \mu \mathrm{m}$.

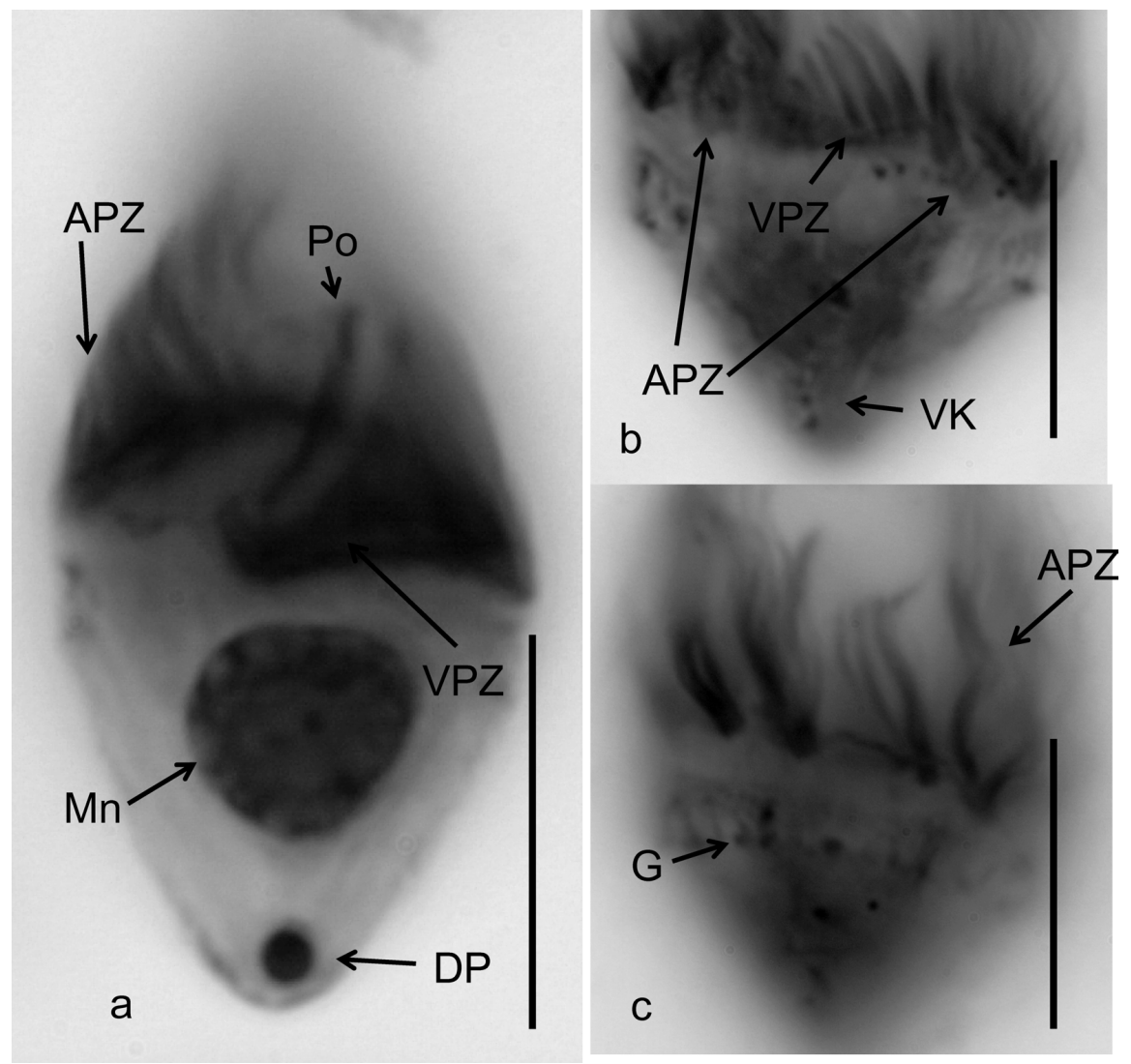

Fig. 16. Microphotographs of protargol-stained Strombidium epidemum. a, ventral view showing anterior polykinetid zone (APZ), ventral polykinetid zone (VPZ), a macronucleus (Mn), paroral (Po) and a dark-stained particle (DP); b, ventral surface showing ventral kinety (VK), APZ and VPZ; c, ventral surface showing APZ and girdle (G) composed of dikinetids with the single kinetosome ciliated. Scale bar: $10 \mu \mathrm{m}$. 
clearly separated from ventral polykinetid zone (VPZ). Anterior polykinetids (APk) of equal length and surrounding anterior end. VPZ composed of 6-7 polykinetids (mean=6.4 polykinetids, $\mathrm{n}=11$ ), lying obliquely in a ventral groove. Paroral (Po) frequently recognizable, a long polykinetid extending anteriorly at the right margin of the oral groove. Girdle $(\mathrm{G})$ dikinetids with the single kinetosome ciliated, completely surrounding the cell equatorially. Ventral kinety (VK) recognizable, usually 3 or 4 kinetids; while kinetid type was not determinable. One macronucleus (Mn) almost spherical, 5-9 $\times 4-8 \mu \mathrm{m}($ mean $=6.7 \times 6.1 \mu \mathrm{m}$, $\mathrm{n}=11$ ), positioned slightly posteriorly within the cell. Trichites inserting around $\mathrm{G}$ and extending internally towards posterior end. One dark-stained particle (DP), 0.5-2 $\mu \mathrm{m}$ (mean $=1.4 \mu \mathrm{m}, \mathrm{n}=9$ ) in diameter, mostly positioned around posterior end.

Remarks and comparisons. The Franklin-Bay population is very similar to the Kingston-Harbour population (Lynn \& Gilron 1993) in many morphological characters such as cell length $(15-21 \mu \mathrm{m}$ vs. $14-23 \mu \mathrm{m})$, APk number (14 vs. 12-15), ventral polykinetid number (6-7 vs. 5-7), girdle kinetid type (dikinetids with the single kinetosome ciliated) and VK (3-4 kinetids vs. 2-4 kinetids). On the other hand, it was slightly different from the Isles-of-Shoals population (Lynn et al. 1988) with respect to cell length (15-21 $\mu \mathrm{m}$ vs. 9-14 $\mu \mathrm{m}$ ), girdle kinetid type (dikinetids vs. monokinetids) and VK (3-4 kinetids vs. not observed). Furthermore, the dark-stained particle and a paroral kinety are newly recognized in this population.

Distribution. These morphological characters might be variable among populations. This species also occurs in various areas, e.g. Arou Beach $\left(43^{\circ} 12^{\prime} \mathrm{N}, 9^{\circ} 07^{\prime} \mathrm{E}\right)$ (Fernandez-Leborans \& Novillo 1992), Cantabrian Sea $\left(43^{\circ} 22^{\prime} \mathrm{N}\right.$, $00^{\circ} 28^{\prime} \mathrm{W}$ ) (Fernandez-Leborans 2001), Plymouth Sound $\left(50^{\circ} 20^{\prime} \mathrm{N}, 4^{\circ} 09^{\prime} \mathrm{W}\right)$ (Leakey et al. 1994), Isles of Shoals $\left(42^{\circ} 59^{\prime} \mathrm{N}, 70^{\circ} 37^{\prime} \mathrm{W}\right)$ (Lynn et al. 1988) and Kingston Harbour $\left(17^{\circ} 58^{\prime} \mathrm{N}, 70^{\circ} 48^{\prime} \mathrm{W}\right)$ (Lynn \& Gilron 1993). It might be a eurythermal species and be widely distributed, at least in the northern hemisphere.

\section{Strombidium cf. inclinatum Montagnes, Taylor \& Lynn, 1990 (Figs $17 \& 18$, Table 2)}

cf. Strombidium inclinatum Montagnes, Taylor \& Lynn,

1990: 321-322, figs 3-8; Modeo et al., 2003: 178-180, figs $3 \mathrm{~h}-\mathrm{n}, 6-7$.

Description. Cell conical posteriorly and cylindrical anteriorly, $12-15 \mu \mathrm{m}($ mean $=13.4 \mu \mathrm{m}, \mathrm{n}=10)$ in length and 9-11 $\mu \mathrm{m}$ (mean $=9.7 \mu \mathrm{m}, \mathrm{n}=10)$ in width. Anterior polykinetid zone (APZ) slanted and continues to ventral polykinetid zone (VPZ). APZ and VPZ composed of 19-21 polykinetids together. Anterior polykinetid length $6-9 \mu \mathrm{m}$ and ventral polykinetid length $2.5-6 \mu \mathrm{m}$. Paroral (Po) frequently recognized. Single macronucleus $(\mathrm{Mn})$ almost spherical, 3.5-6 $\mu \mathrm{m}$ in diameter $($ mean $=4.9 \mu \mathrm{m}, \mathrm{n}=10$ ). Micronucleus not recognized. Girdle (G) subequatorial, composed of $14-15$ dikinetids, at about $1 \mu \mathrm{m}$ intervals,
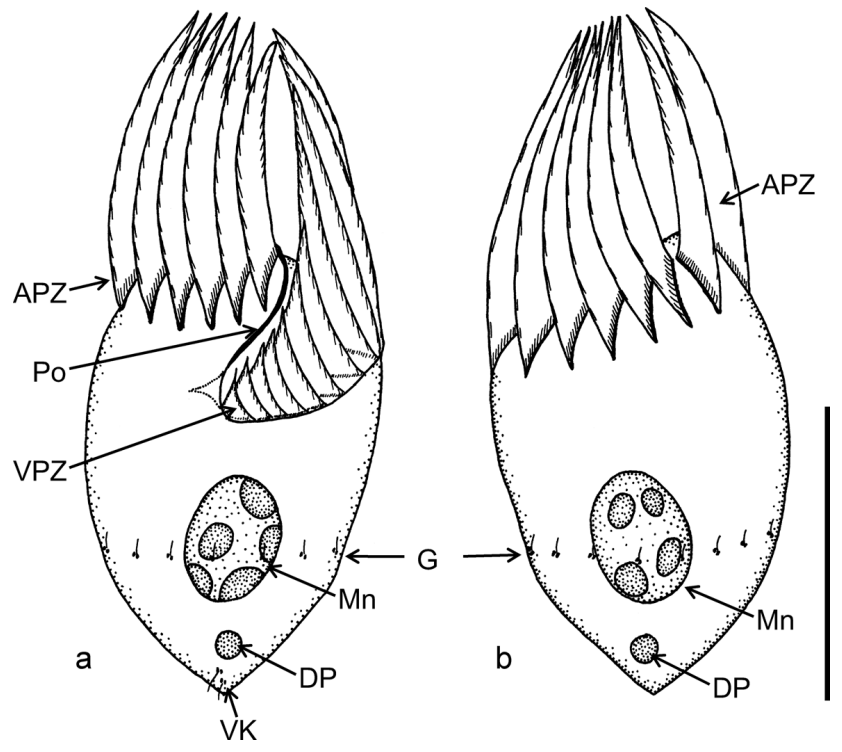

Fig. 17. Schematic figures of protargol-stained Strombidium cf. inclinatum. a, ventral view showing anterior polykinetid zone (APZ), paroral (Po), ventral polykinetid zone (VPZ), a macronucleus $(\mathrm{Mn})$, girdle $(\mathrm{G})$, a dark-stained particle (DP) and ventral kinety (VK); b, dorsal view showing APZ, Mn, G and DP. Scale bar: $10 \mu \mathrm{m}$.

with the single kinetosome ciliated. Ventral kinety (VK) sometimes recognizable, composed of 2 dikinetids with the single kinetosome ciliated. Trichite not recognizable. One dark-stained particle (DP), about $0.8 \mu \mathrm{m}$ in diameter, sometimes positioned near posterior end.

Remarks and comparisons. This species is similar to Strombidium inclinatum sensu Montagnes et al., 1990 (Montagnes et al. 1990) or sensu Modeo et al., 2003 (Modeo et al. 2003) with respect to many morphological characteristics. However, there are some differences: it is smaller in body size $(12-15 \times 9-11 \mu \mathrm{m}$ vs. $12.5-30 \times 12.5-$ $21 \mu \mathrm{m}$ or $14-32 \times 15-28 \mu \mathrm{m})$ and macronucleus size $(3.5-$ $6 \mu \mathrm{m}$ vs. $4-12 \mu \mathrm{m}$ or $6-12.5 \mu \mathrm{m})$, shorter in anterior polykinetid length ( $6-9 \mu \mathrm{m}$ vs. $15 \mu \mathrm{m}$ or $12-17 \mu \mathrm{m})$, fewer number of girdle kinetids (14-15 vs. 44-48 from figures or 32-44), fewer in number of VK kinetids (at most 2 vs. 7-9 or 5-9) and the girdle position is more posterior (subequatorial vs. almost equatorial or equatorial). The latter three inconsistencies are likely to not be trivial. Since cell size is too small to observe morphological characters in detail, this population could not be identified undoubtedly as Strombidium inclinatum in the present study.

\section{Strombidium cf. taylori Martin \& Montagnes, 1993 (Figs $19 \&$ 20, Table 2)}

cf. Strombidium taylori Martin \& Montagnes, 1993: 538539, figs 4-5.

Description. Cell conical posteriorly and cylindrical anteriorly, $26-42 \mu \mathrm{m}$ (mean $=31.1 \mu \mathrm{m}, \mathrm{n}=12)$ in length and $20-31 \mu \mathrm{m}$ (mean $=23.9 \mu \mathrm{m}, \mathrm{n}=12)$ in width. A deep oral 


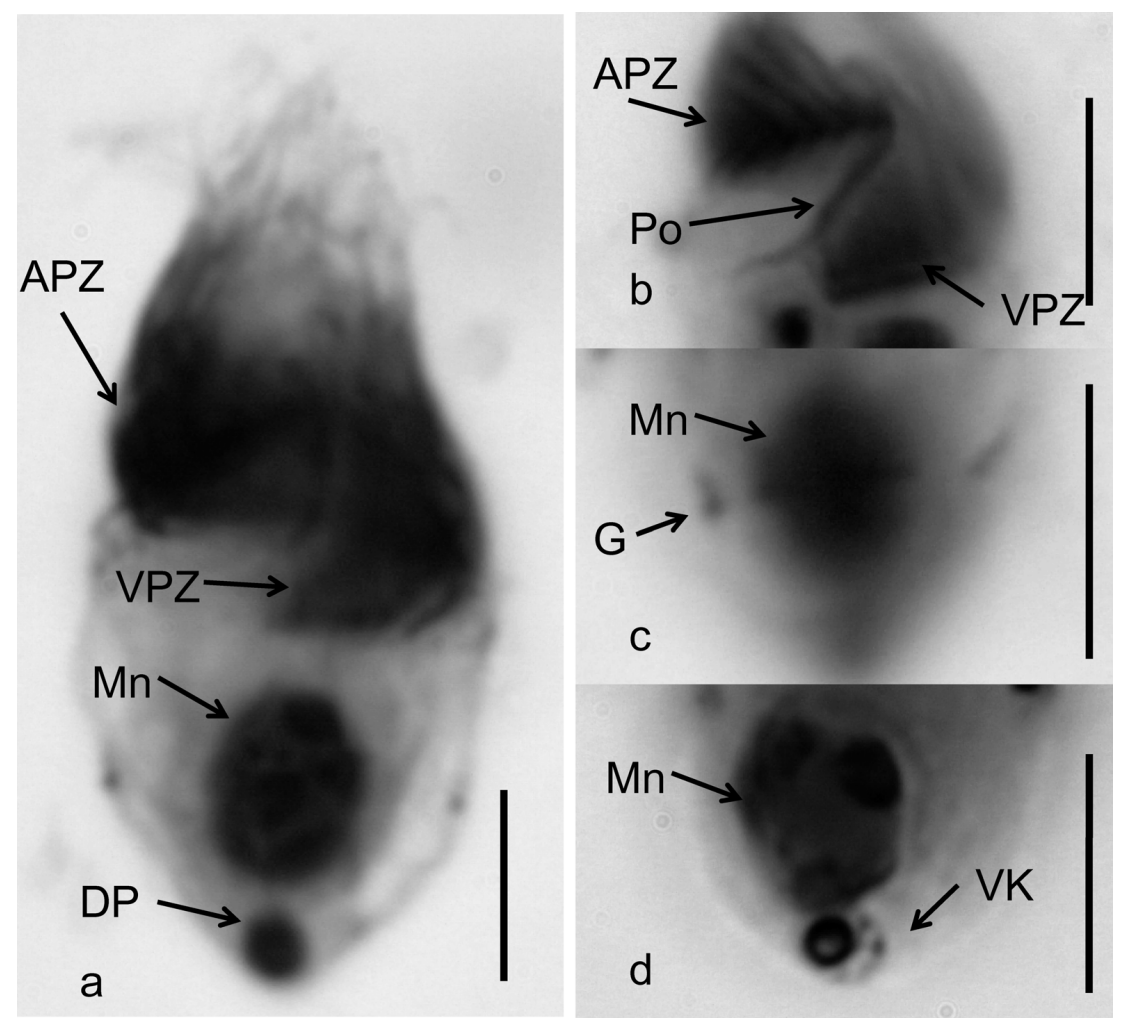

Fig. 18. Microphotographs of protargol-stained Strombidium cf. inclinatum. a, ventral view showing anterior polykinetid zone (APZ), ventral polykinetid zone (VPZ), a macronucleus (Mn) and a dark-stained particle (DP); b, oral area showing paroral (Po), APZ and VPZ; c, equatorial area showing Mn and Girdle (G) composed of dikinetids with the single kinetosome ciliated; d, posterior part showing $\mathrm{Mn}$ and ventral kinety $(\mathrm{VK})$ composed of dikinetids with the single kinetosome ciliated. Scale bar: $5 \mu \mathrm{m}$.

cavity mostly enclosed by the ring of the anterior polykinetid zone (APZ). APZ composed of 15-16 polykinetids (mean $=15.3$ polykinetids, $n=12$ ), distinctly separated from ventral polykinetid zone (VPZ). Anterior polykinetids (APk), frequently tapering towards the apical end, almost of equal length and surrounding anterior end, while one APk is located beside the left margin of the oral groove and has a narrower base and is slightly shifted anteriorly from the ring of the APZ. VPZ composed of 10-14 polykinetids (mean $=12.3$ polykinetids, $n=8$ ), lying in deep oral groove. Ventral polykinetids becoming smaller posteriorly. Paroral kinety not recognizable. Girdle $(\mathrm{G})$, composed of 20-30 dikinetids with the single kinetosome ciliated, surrounding the cell equatorially. Ventral kinety (VK) comprised of 4-6 dikinetids (mean $=4.9$ dikinetids, $\mathrm{n}=6$ ) with the single kinetosome ciliated. One "U"-shaped macronucleus (Mn) positioned around buccal cavity. Thick trichites (Tr) inserting from the anterior neighborhood of girdle and extending internally towards posterior. Many dark-stained particles observable inside.

Remarks and comparisons. This species is similar to Strombidium taylori sensu Martin \& Montagnes, 1993 (Martin \& Montagnes 1993) with respect to various morphometrics, such as length ( $26-42 \mu \mathrm{m}$ vs. $21-37 \mu \mathrm{m})$, width (20-31 $\mu \mathrm{m}$ vs. $17-39 \mu \mathrm{m})$, APk number (15-16 vs. 13-16),

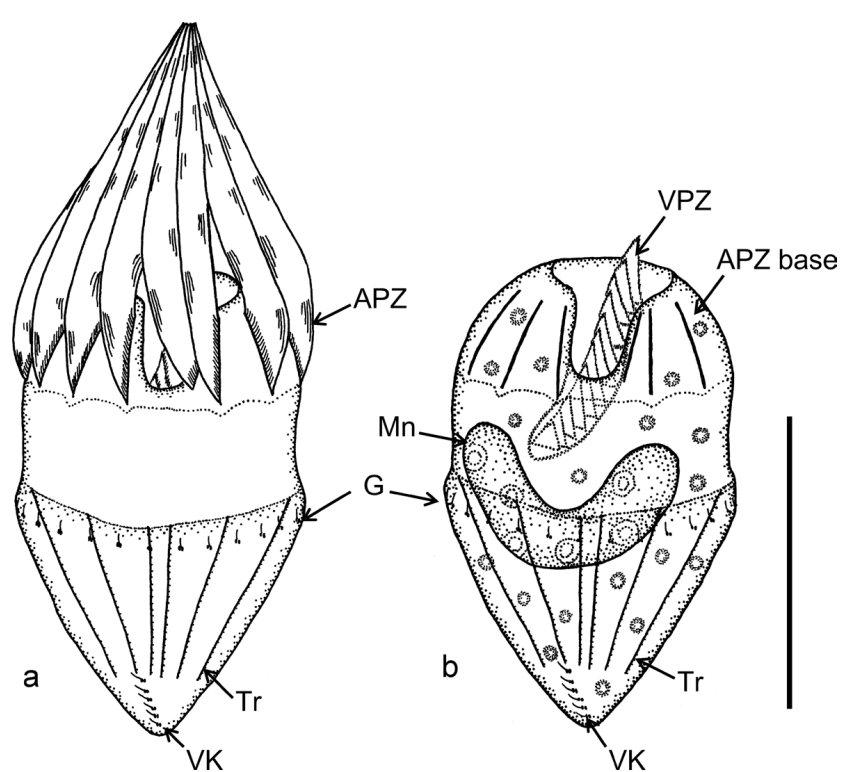

Fig. 19. Schematic figures of protargol-stained Strombidium cf. taylori. a, ventral surface showing anterior polykinetid zone (APZ), girdle (G), trichites (Tr) and ventral kinety (VK); b, ventral view showing ventral polykinetid zone (VPZ), APZ base, a macronucleus (Mn), G, Tr and VK. Scale bar: $20 \mu \mathrm{m}$. 

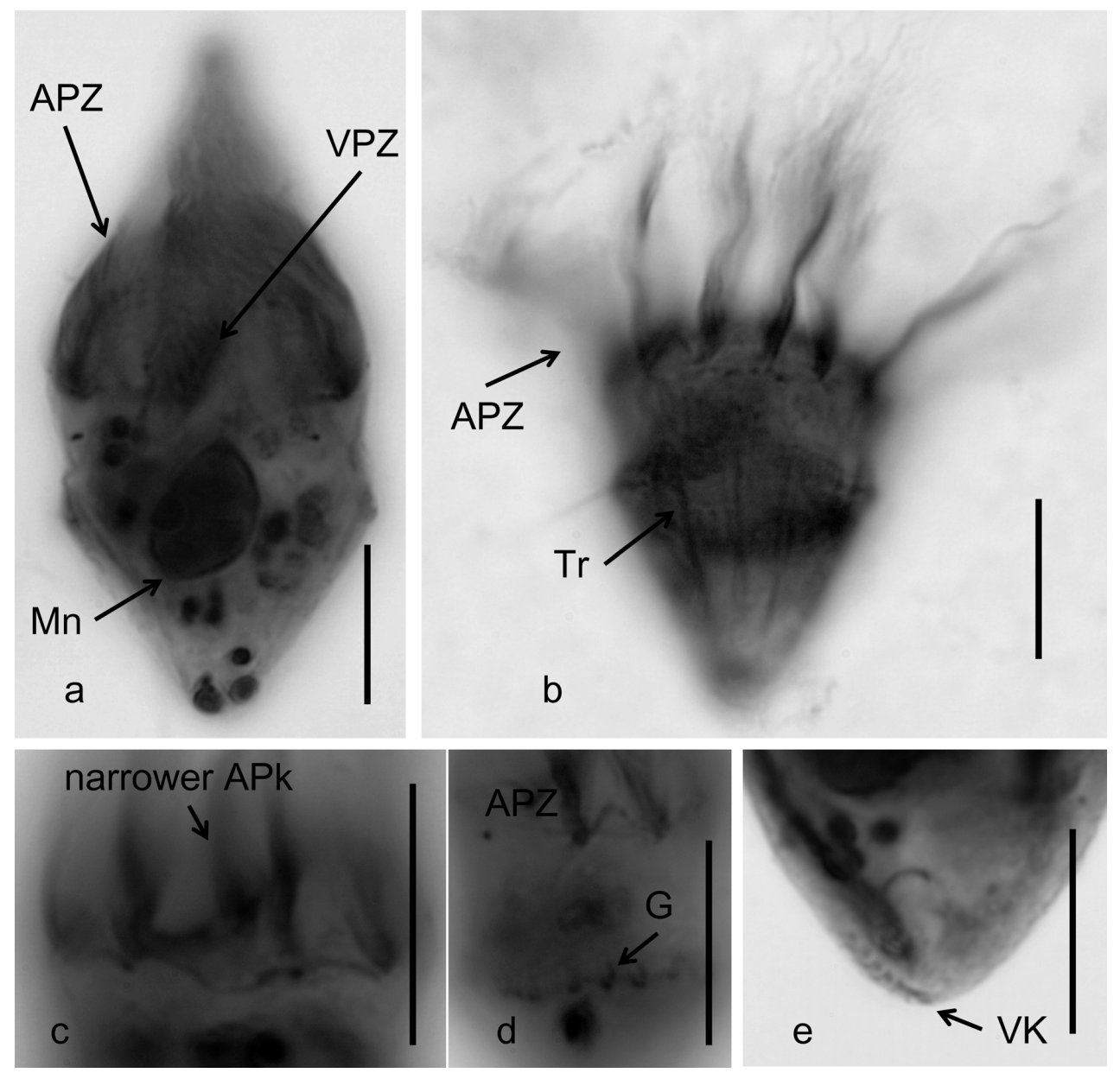

Fig. 20. Microphotographs of protargol-stained Strombidium cf. taylori. a, ventral view showing anterior polykinetid zone (APZ) with tapering anterior polykinetids, ventral polykinetid zone (VPZ) and a macronucleus (Mn); b, dorsal view showing trichites (Tr) and APZ with fanwise anterior polykinetids; c, oral area showing a narrower anterior polykinetid (APk) located beside the left margin of the oral groove; d, equatorial area showing APZ and girdle (G) composed of dikinetids with the single kinetosome ciliated; e, ventral kinety (VK) composed of dikinetids with the single kinetosome ciliated. Scale bar: $10 \mu \mathrm{m}$.

ventral polykinetid number (10-14 vs. 12-15) and macronucleus shape ("U"-shaped). This population, however, has a different arrangement of the APZ and VPZ (distinctly separated vs. not distinctly separated), different style in girdle kinety (dikinetids with the single kinetosome ciliated vs. monokinetids with short cilia) and a different number of girdle kinetids (20-30 vs. more than 40 estimated from figures). From these inconsistencies, this species could not be identified undoubtedly as Strombidium taylori in the present study.

Class Litostomatea Small \& Lynn, 1981

Subclass Haptoria Corliss, 1974

Order Cyclotrichida Jankowski, 1980

Family Mesodiniidae Jankowski, 1980

Genus Myrionecta Jankowski, 1976

Myrionecta rubra (Lohmann, 1908) Jankowski, 1976

(Figs 21 \& 22)

Halteria rubra Lohmann, 1908: 303-304, pl. 17, figs 37-41.
Mesodinium rubrum Hamberger \& Buddenbrock, 1911: 26, fig. 20; Taylor et al., 1971: 397-400, figs 3-7; Lindholm, 1985: 7-16, figs 4-8.

Myrionecta rubra Jankowski, 1976: 168; Petz, 1999: 291292, fig. 8.13; Petz, 2005: 411, figs 14.108a-b, 14.164.

Description. Cell ovoid, composed of larger anterior and smaller posterior semispherical parts, 10-14 $\mu \mathrm{m}$ (mean= $11.7 \mu \mathrm{m}, \mathrm{n}=10)$ in length and $7-10 \mu \mathrm{m}$ (mean $=7.8 \mu \mathrm{m}$, $\mathrm{n}=12)$ in width. Two ovoid macronuclei $(\mathrm{Mn}), 1.5-3.0 \mu \mathrm{m}$ (mean $=1.8 \mu \mathrm{m}, \mathrm{n}=12)$ in diameter, located in the posterior part. One symbiont cryptophyte nucleus (SCN) with nucleolus, $2-3 \mu \mathrm{m}$ in diameter, sometimes observable clearly near Mn. Symbiont chloroplasts (SC), 2-7 nos. (mean=3.3 nos., $\mathrm{n}=12$ ), mainly positioned in the anterior part. Equatorial kinety belt (EKB) composed of 18-23 longitudinal kinety rows $($ mean $=19.8$ rows, $n=12)$ with basal row length of 1.5-2 $\mu \mathrm{m}$. Pre-equatorial kinety belt (PKB) composed of the same row number as observed in EKB with basal row length of about $1.0 \mu \mathrm{m}$. 

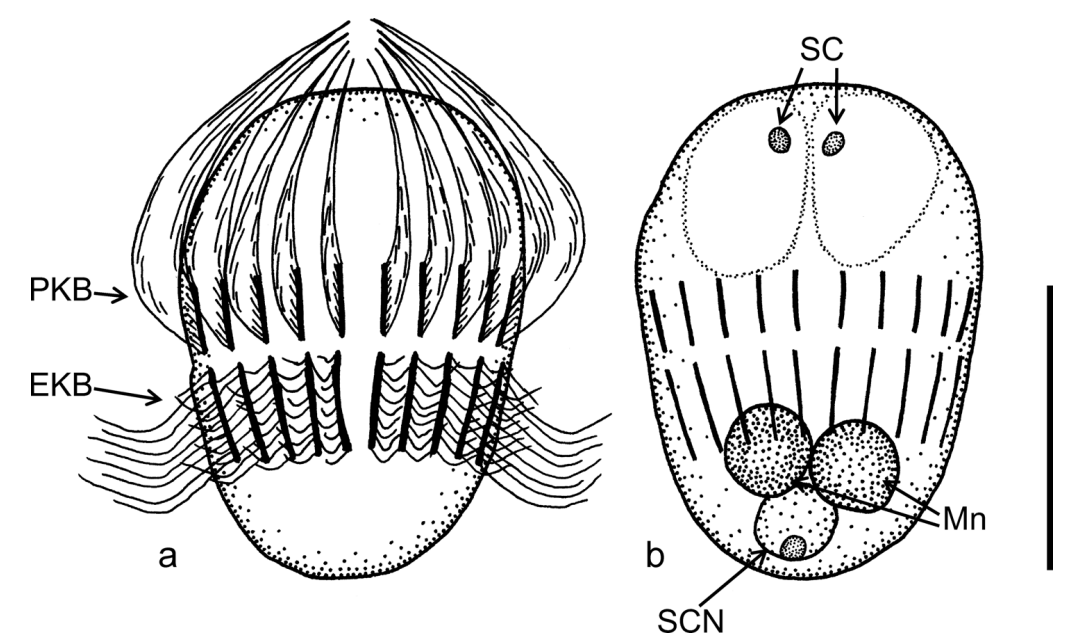

Fig. 21. Schematic figures of protargol-stained Myrionecta rubra. a, lateral view showing pre-equatorial kinety belt (PKB) and equatorial kinety belt (EKB); b, lateral view showing two symbiont chloroplasts (SC), two macronuclei (Mn) and one symbiont cryptophyte nucleus (SCN). Scale bar: $5 \mu \mathrm{m}$.

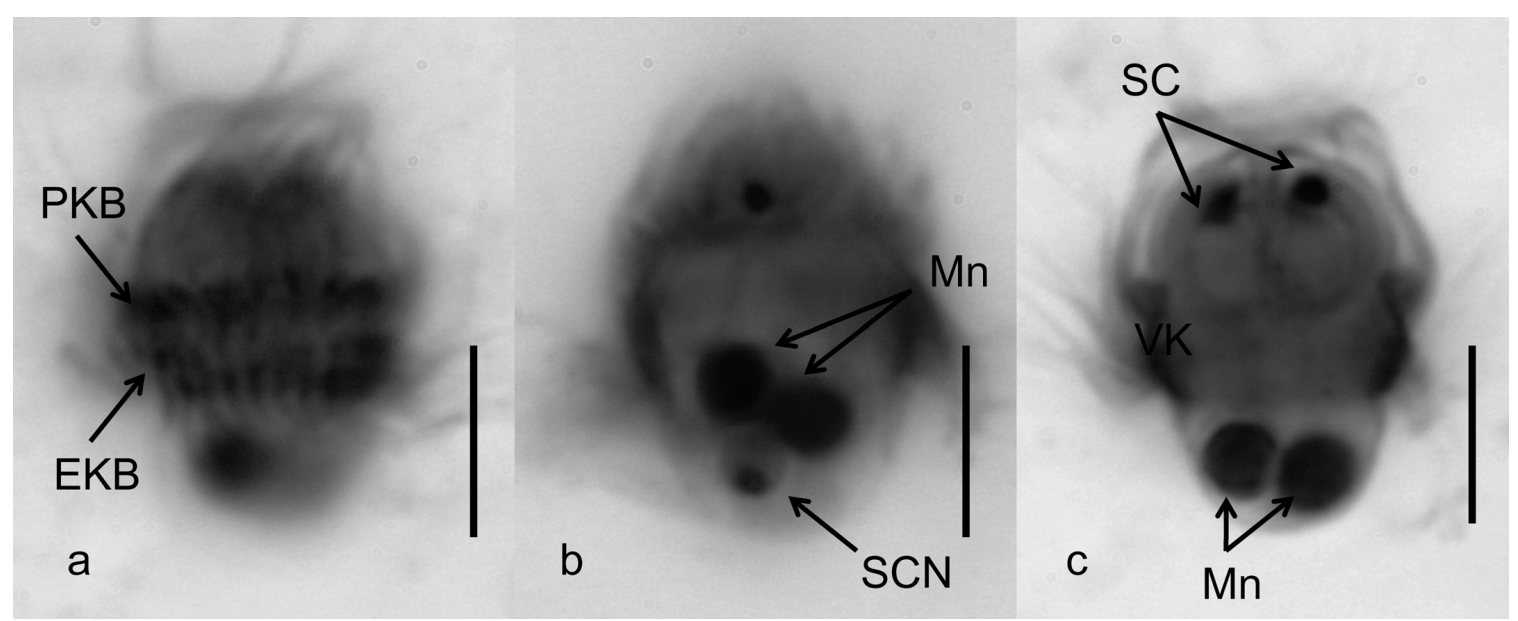

Fig. 22. Microphotographs of protargol-stained Myrionecta rubra. a, lateral surface view showing equatorial kinety belt (EKB) and pre-equatorial kinety belt (PKB); b, lateral transect view showing two macronuclei (Mn) and one symbiont cryptophyte nucleus (SCN); c, lateral transect view showing two symbiont chloroplasts (SC) and two Mn. Scale bar: $5 \mu \mathrm{m}$.

Remarks and comparisons. Although the Franklin-Bay population is very similar to the general description (Strüder-Kypke et al. 2001-2002), it is remarkably biased towards being smaller in body size $(10-14 \mu \mathrm{m}$ vs. $10-70$ $\mu \mathrm{m}$ in length). Probably hence, it exhibited a tendency towards fewer symbiont chloroplasts (2-7 vs. many) and EKB (or PKB) kinety rows (18-23 vs. 20-80), and a different macronucleus position (posterior part vs. central part).

The genus Myrionecta was initially proposed for Mesodinim forms that lack oral tentacles (Jankowski 1976, Small \& Lynn 1985). This criterion however was not widely accepted, because oral tentacles are easily lost and possession of them was recognized in many populations even if it was rare (Lindholm et al. 1988, Crawford 1989). Thereafter Krainer \& Foissner (1990) proposed new keys to the genus Myrionecta; cell form (anterior portion larger than poste- rior) and PKB kinety (seemingly composed of dikinetids) are criteria in distinguishing Myrionecta from Mesodinium. After this proposal, the name Myrionceta rubra has been gradually accepted (e.g. Petz 1999, Lynn \& Small 2000), while the change in nomenclature is sometimes debated owing to great variation in cell morphology (Crawford \& Lindholm 1997).

Distribution. Geographical distribution of this species is extremely wide, extending from the polar seas to equatorial waters (e.g. Taylor et al. 1971, Petz 1999, Petz 2005). Even in Antarctic saline lakes (Gibson et al. 1997) and in the polar sea-ice (Lizotte 2003), this species is one of the dominant autotrophs. It occurred at 1,200 cells $\mathrm{L}^{-1}$ and was predominant $(50 \%)$ among the planktonic ciliates; hence, it might play an important ecological role below the sea ice in Franklin Bay. 


\section{Acknowledgments}

We would like to thank Drs. H. Sasaki, H. Hattori, M. Sanpei, M. Fukuchi and L. Fortier for their planning in this study and for giving us a chance to access the ice-covered arctic sea. Field sampling was generously aided by the CASES Leg 6 members; we particularly thank Mr. S. Yamamoto (Soka Univ.) and the crew of the Canadian Coastal Guard icebreaker Amundsen. This study was partially supported by a Grant-in-Aid for Scientific Research (C) from JSPS (no. 20570089).

\section{References}

Alekperov IH, Mamajeva NV (1992) Planktonic infusoria from the Chuckchee and the Bering Seas. Zool Zh 71: 5-14. (in Russian with English abstract)

Andersen P, Sørensen HM (1986) Population dynamics and trophic coupling in pelagic microorganisms in eutrophic coastal waters. Mar Ecol Prog Ser 33: 99-109.

Azam F, Fenchel F, Field JG, Gray JS, Meyer-Reil LA, Thingstad F (1983) The ecological role of water-column microbes in the sea. Mar Ecol Prog Ser 10: 257-263.

Crawford DW (1989) Mesodinium rubrum: the phytoplankter that wasn't. Mar Ecol Prog Ser 58: 161-174.

Crawford DW, Lindholm T (1997) Some observations on vertical distribution and migration of the phototrophic ciliate Mesodinium rubrum (=Myrionecta rubra) in a stratified brackish inlet. Aquat Microb Ecol 13: 267-274.

Dieckmann GS, Hellmer HH (2003) The importance of sea ice: an overview. In: Sea Ice: An Introduction to its Physics, Chemistry, Biology and Geology (eds Thomas DN, Dieckmann GS). Blackwell Science, Oxford, pp. 1-21.

Fauré-Fremiet E (1924) Contribution a la connaissance des Infusoires Planktoniques. Bull Biol Fr Belg, Suppl 6: 1-171.

Fernandez-Leborans G (2001) Relative importance of protozoan functional groups in three marine sublittoral areas. J Mar Biol Ass U K 81: 735-750.

Fernandez-Leborans G, Fernandez-Fernandez D (1999) Seasonal characterization of a marine sublittoral area using epibenthic protist communities. Bull Mar Sci 65: 631-644.

Fernandez-Leborans G, Novillo A (1992) Hazard evaluation of lead effects using marine protozoan communities. Aquat Sci 54: 128-140.

Fortier L, Barber DG (2008) An introduction to the Canadian Arctic Shelf Exchange Study. In: On Thin Ice: a Synthesis of the Canadian Arctic Shelf Exchange Study (CASES) (eds Fortier L, Barber D, Michaud J). Aboriginal Issues Press, Winnipeg, pp. $1-11$.

Gibson JAE, Swadling KM, Pitman TM, Burton HR (1997) Overwintering population of Mesodinium rubrum (Ciliophora: Haptorida) in lakes of the Vestfold Hills, East Antarctica. Polar Biol 17: 175-179.

Grey J, Laybourn-Parry J, Leakey RJG, McMinn A (1997) Temporal patterns of protozooplankton abundance and their food in Ellis Fjord, Princess Elizabeth Land, Eastern Antarctica. Est Coast Shelf Sci 45: 17-25.

Hamburger C, Buddenbrock W (1911) Nordische Ciliata mit
Ausschluss der Tintinnoidea. Nord Plankton 13: 1-152.

Jankowski AW (1976) Revision of a system of cyrtophorines. In: Materials of the II All-Union Conference of Protozoologists, Part I, General Protozoology (eds Markevich AP, Yu I). Naukova Dumka, Kieb, pp. 167-168.

Jensen F, Hansen BW (2000) Ciliates and heterotrophic dinoflagellates in the marginal ice zone of the central Barents Sea during spring. J Mar Biol Ass U K 80: 45-54.

Jerome CA, Montagnes DJS, Taylor FJR (1993) The effect of the quantitative protargol stain and Lugol's and Bouin's fixative on cell size: a more accurate estimate of ciliate species biomass. J Eukaryot Microbiol 40: 254-259.

Kahal A (1932) Urtiere oder Protozoa I. Wimpertiere oder Ciliata (Infusoria). 3. Spirotricha. In: Die Tierwelt Deutshlands und der Angrenzenden Meeresteile 25 (ed Dahl F). Gustav Fisher, Jena, pp. 399-650.

Knox GA (1994) The Biology of the Southern Ocean. Cambridge University Press, Cambridge, 444 pp.

Krainer, K-H \& Foissner W (1990) Revision of the genus Askenasia Blochmann, 1895, with proposal of two new species, and description of Rhabdoaskenasia minima n. g., n. sp. (Ciliophoa, Cyclotrichida). J Protozool 37: 414-427.

Leakey RJG, Burkill PH, Sleigh MA (1994) A comparison of fixative for the estimation of abundance and biovolume of marine planktonic ciliate population. J Plankton Res 16: 375-389.

Leegaard C (1915) Untersuchungen über einige Planktonciliaten des Meeres. Nyt Mag Naturvidensk 53: 1-37.

Lindholm T (1985) Mesodinium rubrum - a unique photosynthetic ciliate. Adv Aquat Microbiol 3: 1-48.

Lindholm T, Lindroos P, Mörk AC (1988) Ultrastructure of the photosynthetic ciliate Mesodinium rubrum. Biosystems 21: 141-149.

Lizotte MP (2003) The microbiology of sea ice. In: Sea Ice: An Introduction to its Physics, Chemistry, Biology and Geology (eds Thomas DN, Dieckmann GS). Blackwell Science, Oxford, pp. 184-210.

Lohmann H (1908) Untersuchungen zur Feststellung des vollständigen Gehaltes des Meeres an Plankton. Wiss Meeresunter 10: 129-370.

Lynn DH, Gilron GL (1993) Strombidiid ciliates from coastal waters near Kingston Harbour, Jamaica (Ciliophora, Oligotrichia, Strombidiidae). J Mar Biol Ass U K 73: 47-65.

Lynn DH, Montagnes DJS (1988) Taxonomic description of some conspicuous species of Strobilidiine ciliates (Ciliophora: Choreotrichida) from the Isles of Shoals, Gulf of Maine. J Mar Biol Ass U K 68: 639-658.

Lynn DH, Montagnes DMS, Small EB (1988) Taxonomic descriptions of some conspicuous species in the family Strombidiidae (Ciliophora: Oligotrichida) from the Isles of Shoals, Gulf of Maine. J Mar Biol Ass U K 68: 259-276.

Lynn DH, Small EB (2000) Phylum Ciliophora. In: The Illustrated Guide to the Protozoa (eds Lee JJ, Leedale GF, Bradbury P). Allen Press, Lawrence, pp. 371-656.

Martin AJ, Montagnes DJS (1993) Winter ciliates in British Columbian Fjord: six new species and an analysis of ciliate putative prey. J Eukaryot Microbiol 40: 535-549.

Meunier A (1910) Microplankton des Mers de Barents et de Kara. Duc d'Orléans. Campagne arctique de 1907. Imprimerie scien- 
tifique Charles Bulens: Bruxelles, Belgium, 355 pp.

Modeo L, Petroni G, Rosati G, Montagnes DJS (2003) A multidisciplinary approach to describe protists: redescription of $\mathrm{No}$ vistrombidium testaceum Anigstein 1914 and Strombidium inclinatum Montagnes, Taylor, and Lynn 1990 (Ciliophora, Oligotrichia). J Eukaryot Microbiol 50: 175-189.

Montagnes DJS, Lynn DH (1987) A quantitative protargol stain (QPS) for ciliates: method description and test of its quantitative nature. Mar Microb Food Webs 2: 83-93.

Montagnes DJS, Lynn DH, Stoecker DK, Small EB (1988) Taxonomic descriptions of one new species and redesctiption of four species in the family Strombidiidae (Ciliophora, Oligotrichida). J Protozool 35: 189-197.

Montagnes DJS, Taylor FJR, Lynn DH (1990) Strombidium inclinatum n. sp. and a reassessment of Strombidium sulcatum Claparède and Lachmann (Ciliophora). J Protozool 37: 318-323.

Parsons TR, Maita Y, Lalli CM (1984) A Manual of Chemical and Biological Methods for Seawater Analysis. Pergamon Press, Oxford, 173 pp.

Pettigrosso RE (2003) Planktonic ciliates Choreotrichida and Strombidiida from the inner zone of Bahía Blanca Estuary, Argentina. Iheringia, Sér Zool, Porto Alegre 93: 117-126.

Petz W (1999) Ciliophora. In: South Atlantic Zooplankton (ed Boltovskoy D). Backhuys Publishers, Leiden, pp. 265-319.

Petz W (2005) Ciliates. In: Antarctic Marine Protists (eds Scott FJ, Marchant HJ). Australian Biological Resources Study, Canberra, pp. 347-448.

Schnack-Schiel SB (2003) The macrobiology of sea ice. In: Sea Ice: An Introduction to its Physics, Chemistry, Biology and Geology (eds Thomas DN, Dieckmann GS). Blackwell Science,
Oxford, pp. 211-239.

Small EB, Lynn DH (1985) Phylum Ciliophora Doflein, 1901. In: An Illustrated Guide to the Protozoa (eds Lee JJ, Hunter SH, Bovee EC). Society of Protozoologists, Lawrence, pp. 393-575.

Strüder-Kypke MC, Kypke ER, Agatha S, Warwick J. Montagnes DJS (2000-2001) The user-friendly guide to coastal planktonic ciliates. Available at: http://www.liv.ac.uk/ciliate (accessed on 26 Nov. 2009)

Suzuki T (1999) Standing crops of planktonic ciliates and their prey organisms, picoplankton and nanoplankton, around the continental shelf break in the East China Sea. La mer 37: 21-29.

Suzuki T, Taniguchi A (1998) Standing crops and vertical distribution of four groups of marine planktonic ciliates in relation of phytoplankton chlorophyll $a$. Mar Biol 132: 375-382.

Taylor FJR, Blackbourn DJ, Blackbourn J (1971) The red-water ciliate Mesodinium rubrum and its "incomplete symbionts": a review including new ultrastructural observations. J Fish Res Board Can 28: 391-407.

Trottet A, Roy S, Tamigneaux E, Lovejoy C (2007) Importance of heterotrophic planktonic communities in a mussel culture environment: the Grande Entrée lagoon, Magdalen Islands (Québec, Canada). Mar Biol 151: 377-392.

Wickham SA, Berninger UG (2007) Krill larvae, copepods and the microbial food web: interactions during the Antarctic fall. Aquat Microb Ecol 46: 1-13.

Wilbert N (1975) Eine verbesserte Technik der Protargolimprägnation für Ciliaten. Mikrokosmos 64: 171-179.

Wulff A (1919) Ueber des Kleinplankton der Barentssee. Wiss Meeresunters, Abt Helgoland 13: 95-124. 